Prepared in cooperation with the National Park Service

\title{
Geologic Map of Chickasaw National Recreation Area, Murray County, Oklahoma
}
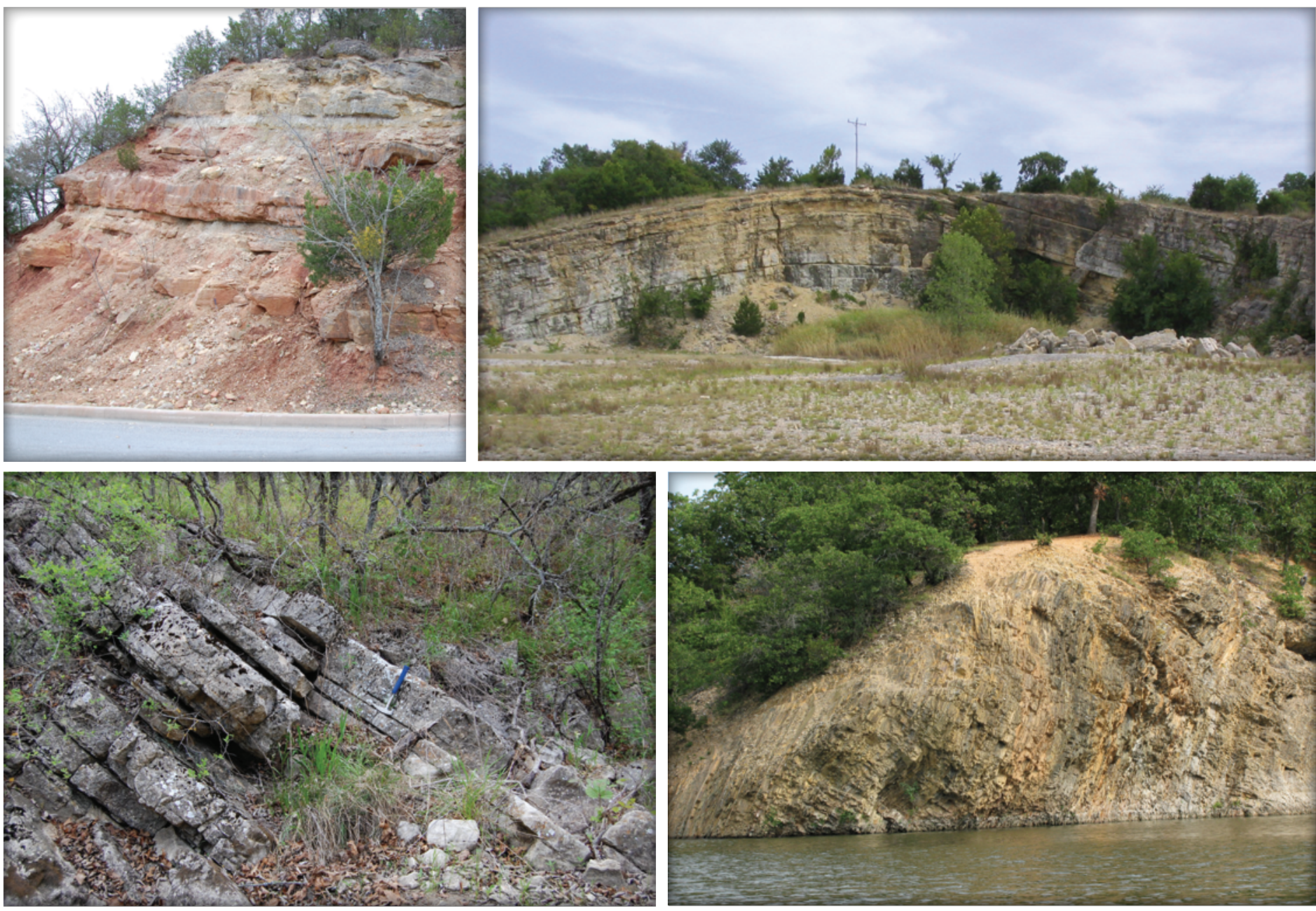

Pamphlet to accompany

Scientific Investigations Map 3258 


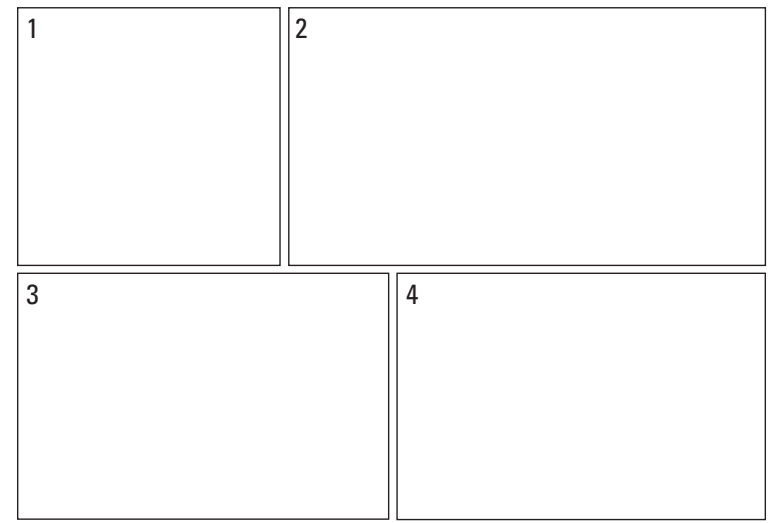

Cover photographs:

1 Massive sandstone, Vanoss Formation (Pvs), see fig. 5.

2 Old abandoned quarry exposing Hunton Group (DSOh) and crest of Tishomingo anticline in southeastern part of map area (looking east-southest), see map sheet. 3 Lower Hunton Group (SOhl, Cochrane Formation), see fig. 4.

4 Woodford Shale (MDsw), see fig. 5. 


\section{Geologic Map of Chickasaw National Recreation Area, Murray County, Oklahoma}

By Charles D. Blome, David J. Lidke, Ronald R. Wahl, and James A. Golab

Prepared in cooperation with the National Park Service

Pamphlet to accompany

Scientific Investigations Map 3258 


\title{
U.S. Department of the Interior SALLY JEWELL, Secretary
}

\section{U.S. Geological Survey Suzette M. Kimball, Acting Director}

\author{
U.S. Geological Survey, Reston, Virginia: 2013 \\ Revised May 8, 2014
}

\begin{abstract}
For more information on the USGS - the Federal source for science about the Earth, its natural and living resources, natural hazards, and the environment, visit http://WWW.usgs.gov or call 1-888-ASK-USGS.

For an overview of USGS information products, including maps, imagery, and publications, visit $h t t p: / / W w w . u s g s . g o v / p u b p r o d$

To order this and other USGS information products, visit http://store.usgs.gov
\end{abstract}

Any use of trade, firm, or product names is for descriptive purposes only and does not imply endorsement by the U.S. Government.

Although this information product, for the most part, is in the public domain, it also may contain copyrighted materials as noted in the text. Permission to reproduce copyrighted items must be secured from the copyright owner.

Suggested citation:

Blome, C.D., Lidke, D.J., Wahl, R.R., and Golab, J.A., 2013, Geologic map of Chickasaw National Recreation Area, Murray County, Oklahoma (rev. May 8, 2014): U.S. Geological Survey Scientific Investigations Map 3258, 28 p., 1 sheet, scale 1:24,000, http://pubs.usgs.gov/sim/3258/. 


\section{Contents}

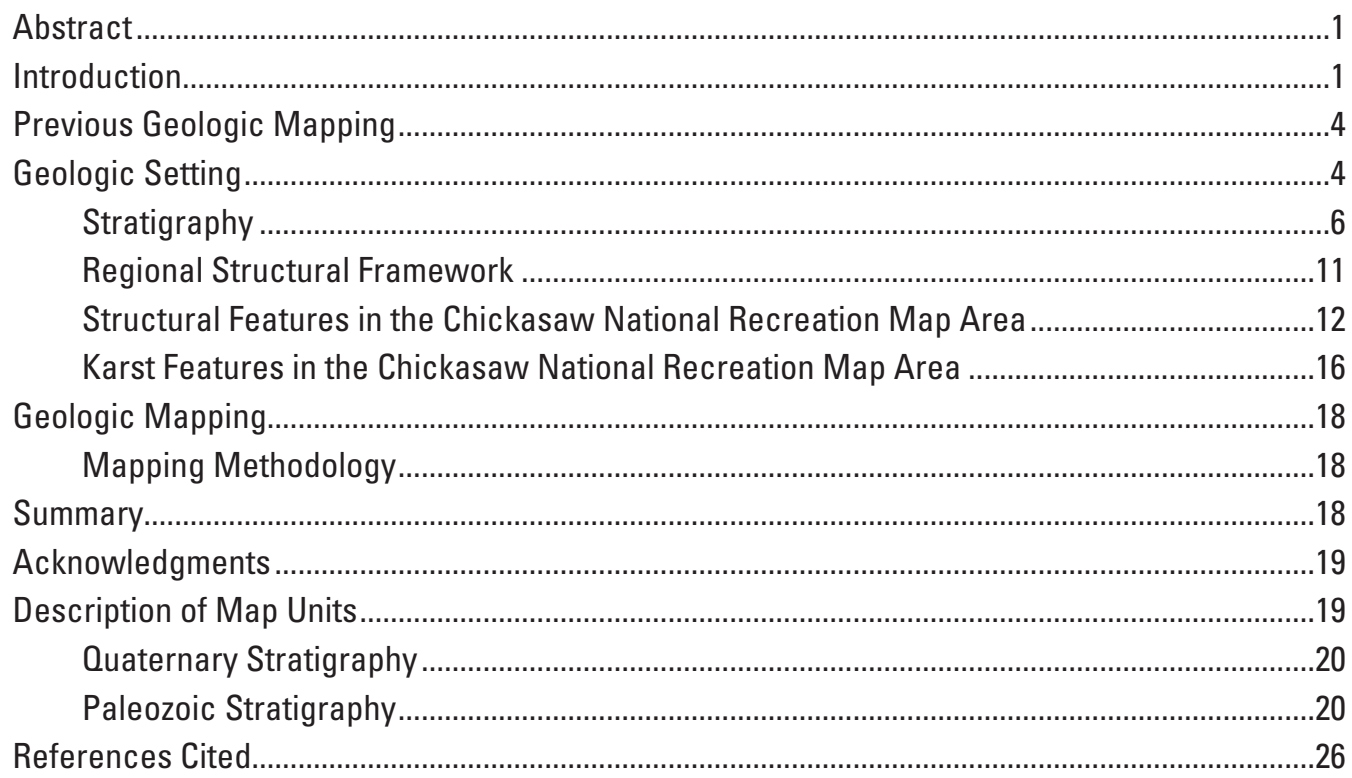

\section{Figures}

1. Location of Chickasaw National Recreation Area, Murray County, Oklahoma, including outline of the map area (also shown on map sheet).....

2. Generalized geology of the Arbuckle-Simpson aquifer area, Oklahoma. Survey blocks A-D from the airborne electromagnetic geophysical survey of Smith and others, 2009.

3. Major structural features in the Hunton anticline area ...................................................5

4. Photographs of Ordovician to Devonian units exposed in and nearby Chickasaw National Recreation Area.

5. Photographs of Devonian, Mississippian, and Pennsylvanian units exposed in and nearby Chickasaw National Recreation Area

6. Map showing major structural features and related Pennsylvanian-age angular unconformities in and nearby the Chickasaw National Recreation Area (also shown on map sheet).

7. Example of circular-shaped hills present in the eastern part of the map area and areas to the east

\section{Tables}

1. Comparison of time-stratigraphic, lithostratigraphic, and hydrostratigraphic units exposed in Chickasaw National Recreation Map Area and their correlation with North American geologic stages

2. Basic information for wells shown on the geologic map and in the cross sections (only shown on map sheet) 


\section{Sheet}

1. Geologic map of Chickasaw National Recreation Area, Murray County, Oklahoma ... link

\section{Conversion Factors}

Inch/Pound to SI

\begin{tabular}{|c|c|c|}
\hline Multiply & By & To obtain \\
\hline \multicolumn{3}{|c|}{ Length } \\
\hline inch (in.) & 2.54 & centimeter $(\mathrm{cm})$ \\
\hline inch (in.) & 25.4 & millimeter (mm) \\
\hline foot (ft) & 0.3048 & meter $(\mathrm{m})$ \\
\hline mile (mi) & 1.609 & kilometer $(\mathrm{km})$ \\
\hline \multicolumn{3}{|c|}{ Area } \\
\hline square mile $\left(\mathrm{mi}^{2}\right)$ & 2.590 & square kilometer $\left(\mathrm{km}^{2}\right)$ \\
\hline \multicolumn{3}{|c|}{ Mass } \\
\hline ton & 0.9072 & metric ton \\
\hline
\end{tabular}

SI to Inch/Pound

\begin{tabular}{llll}
\hline \multicolumn{1}{c}{ Multiply } & \multicolumn{1}{c}{ By } & \multicolumn{1}{c}{ To obtain } \\
\hline centimeter $(\mathrm{cm})$ & Length & \\
meter $(\mathrm{m})$ & 0.3937 & & inch (in.) \\
kilometer $(\mathrm{km})$ & 3.281 & foot (ft) & mile (mi) \\
\hline square kilometer $\left(\mathrm{km}^{2}\right)$ & 0.6214 & & square mile $\left(\mathrm{mi}^{2}\right)$ \\
\hline & & Area & \\
\hline metric ton & 0.3861 & & tons \\
\hline
\end{tabular}

Vertical coordinate information is referenced to National Geodetic Vertical Datum of 1929

Horizontal coordinate information is referenced to North American Datum of 1983 (NAD 83)

Altitude, as used in this report, refers to distance above the vertical datum. 


\title{
Geologic Map of Chickasaw National Recreation Area, Murray County, Oklahoma
}

\author{
By Charles D. Blome, David J. Lidke, Ronald R. Wahl, and James A. Golab
}

\section{Abstract}

This 1:24,000-scale geologic map is a compilation of previous geologic maps and new geologic mapping of areas in and around Chickasaw National Recreation Area. The geologic map includes revisions of numerous unit contacts and faults and a number of previously "undifferentiated" rock units were subdivided in some areas. Numerous circularshaped hills in and around Chickasaw National Recreation Area are probably the result of karst-related collapse and may represent the erosional remnants of large, exhumed sinkholes.

Geospatial registration of existing, smaller scale (1:72,000- and 1:100,000-scale) geologic maps of the area and construction of an accurate Geographic Information System (GIS) database preceded 2 years of fieldwork wherein previously mapped geology (unit contacts and faults) was verified and new geologic mapping was carried out. The geologic map of Chickasaw National Recreation Area and this pamphlet include information pertaining to how the geologic units and structural features in the map area relate to the formation of the northern Arbuckle Mountains and its Arbuckle-Simpson aquifer. The development of an accurate geospatial GIS database and the use of a handheld computer in the field greatly increased both the accuracy and efficiency in producing the 1:24,000-scale geologic map.

\section{Introduction}

Chickasaw National Recreation Area was originally known as Sulphur Springs Reservation, which in 1902 was renamed Platt National Park through an agreement with the Chickasaw and Choctaw Indian Nations and the Federal Government. The Chickasaw Nation sold the land to the government in order to protect the unique freshwater and mineral springs that discharge into Rock Creek and its principal tributary, Travertine Creek (fig. 1). Following World War II, the Park underwent minor expansion in 1950, and in the 1970s, the Park merged with Arbuckle Recreation Area to become Chickasaw National Recreation Area, commonly abbreviated as CNRA. The CNRA's main office is located in the city of Sulphur, Oklahoma (fig. 1).
Since the turn of the twentieth century, several flowing artesian wells have been drilled within and adjacent to CNRA. Discharge from many of the springs in the northern part of CNRA and water levels in surrounding wells have declined substantially during the past 80 years according to Hanson and Cates (1994). The springs and wells in and around CNRA are also a part of the Arbuckle-Simpson aquifer, an aquifer system that underlies more than 500 square miles $\left(\mathrm{mi}^{2}\right)$ in south-central Oklahoma. The Arbuckle-Simpson aquifer is the principal water source for the populations of Sulphur, Dougherty, and numerous other surrounding cities and towns, such as Ada (located northeast of the map area)

Local, Federal, and State agencies, as well as private and public organizations, have recognized the need for a comprehensive study of the Arbuckle-Simpson aquifer for over a decade. In May, 2003, the State of Oklahoma passed Senate Bill 288, which imposed a moratorium on the issuance of any temporary groundwater permit for municipal or public water supply use inside any county that overlays, as a whole or in part, a "sensitive sole-source groundwater basin." The ArbuckleSimpson aquifer became the only sole-source groundwater basin in Oklahoma after the U.S. Environmental Protection Agency (EPA) designated the eastern portion of the ArbuckleSimpson aquifer (Hunton anticline area, fig. 2) to be a solesource aquifer. In 2004, the State of Oklahoma, in cooperation with the Bureau of Reclamation, funded the 5-year ArbuckleSimpson Hydrology Study (ASHS, http://www.owrb.ok.gov/ studies/groundwater/arbuckle_simpson/arbuckle_study.php).

Research on the Arbuckle-Simpson aquifer was a multiagency effort with input from the Oklahoma Water Resources Board (OWRB), the U.S. Geological Survey (USGS, Oklahoma City and Denver offices), Oklahoma Geological Survey (OGS, Norman), University of Oklahoma (OU, Norman), Oklahoma State University (OSU, Stillwater), and other State and local agencies.

The first 3 years of the ASHS largely focused on monitoring and evaluating various aspects of the aquifer, including groundwater and surface-water flow, the hydrologic budget, and geologic framework. Characterizing the surface and subsurface geologic framework of this aquifer system involved geologic mapping, three-dimensional (3-D) EarthVision ${ }^{\mathrm{TM}}$ (EV) modeling (Dynamic Graphics, Inc. http://www.dgi.com/ earthvision/evmain.html), and several ground and airborne 


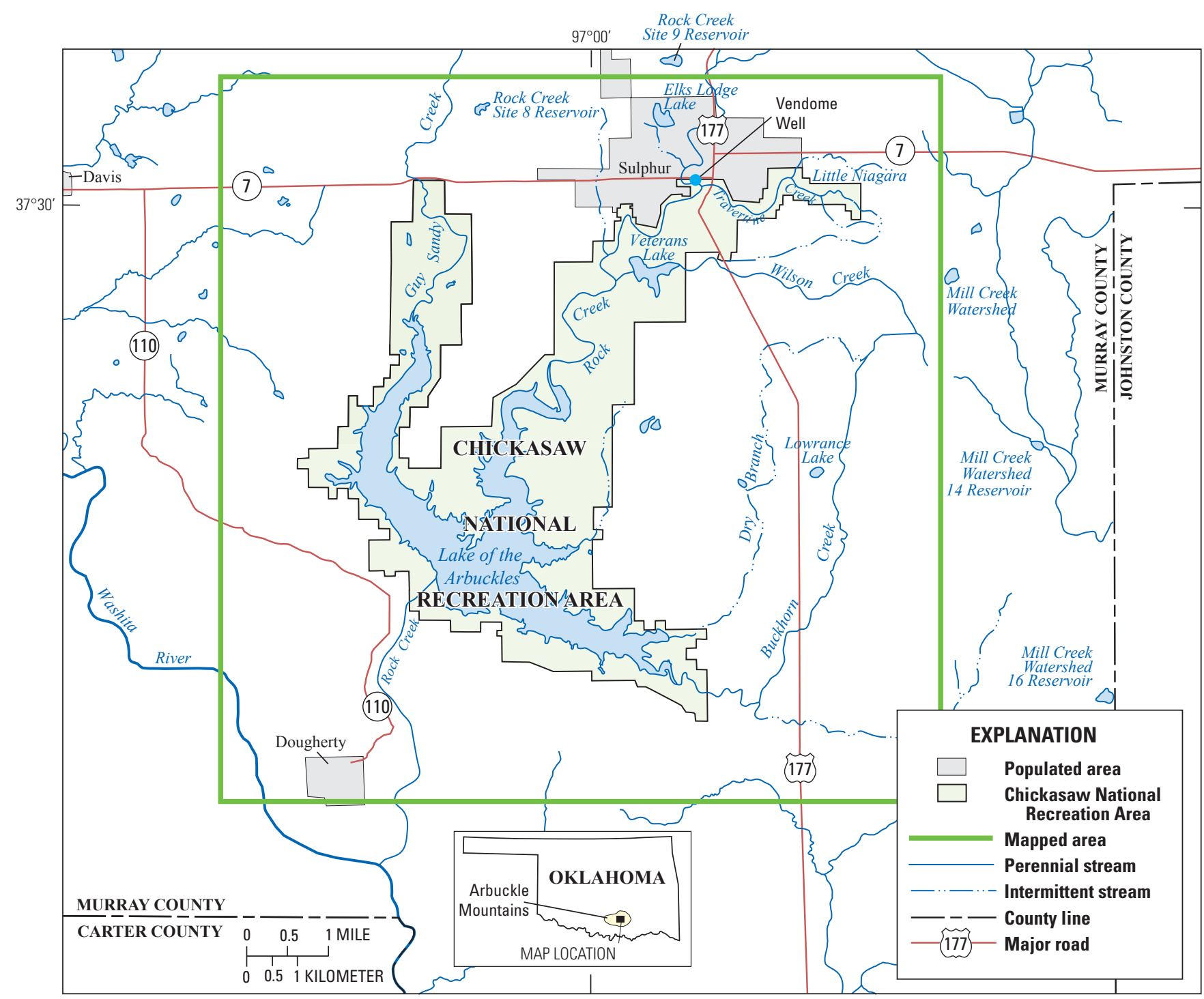

Figure 1. Location of Chickasaw National Recreation Area, Murray County, Oklahoma, including outline of the map area (also shown on map sheet).

geophysical surveys. The latter part of the study concentrated on developing groundwater and surface-water models and evaluating instream-flow requirements. Summary results of the 5-year Arbuckle-Simpson Hydrology Study are available at: http://www.owrb.ok.gov/studies/groundwater/arbuckle_ simpson/pdf/09_report_burec.pdf.

One of the first tasks of the USGS National Cooperative Geologic Mapping Program (NCGMP) project, entitled "Geologic Framework of mid-Continent Carbonate Aquifers," was to conduct a helicopter electromagnetic (HEM) geophysical survey over select parts of the water-producing Hunton anticline area (Smith and others, 2009, 2011). This HEM survey, flown over four areas in the Hunton anticline area in 2007 (fig. 2), provided subsurface details of the electrical resistivity of the geology up to $150 \mathrm{~m}(492 \mathrm{ft})$ in depth. Electromagnetic data acquired from the survey were used to: (1) more precisely locate mapped faults, (2) identify shallow faults that have no recognizable surface expression, (3) refine the outcrops of the lithostratigraphic units, and (4) map the depth and extent of shallow epikarst. Three-dimensional depth sections of the HEM survey blocks B and D (fig. 2) are shown and discussed in Smith and others $(2009,2011)$.

Ground gravity, audiomagnetotelluric (AMT), electromagnetic, and seismic geophysical methods were used to study deeper parts of the Arbuckle-Simpson aquifer, ranging from 900-3,500 ft (275-1,068 m), map fresh/saline-groundwater, and investigate complex fault geometry. Gravity data were used to define the buried extensions of major faults beneath CNRA (Scheirer and Scheirer, 2006; Scheirer and Aboud, 2008). Audiomagnetotelluric ground geophysical stations in areas of spring-water discharge in CNRA helped to map the transition between freshwater springs in the east and saline 


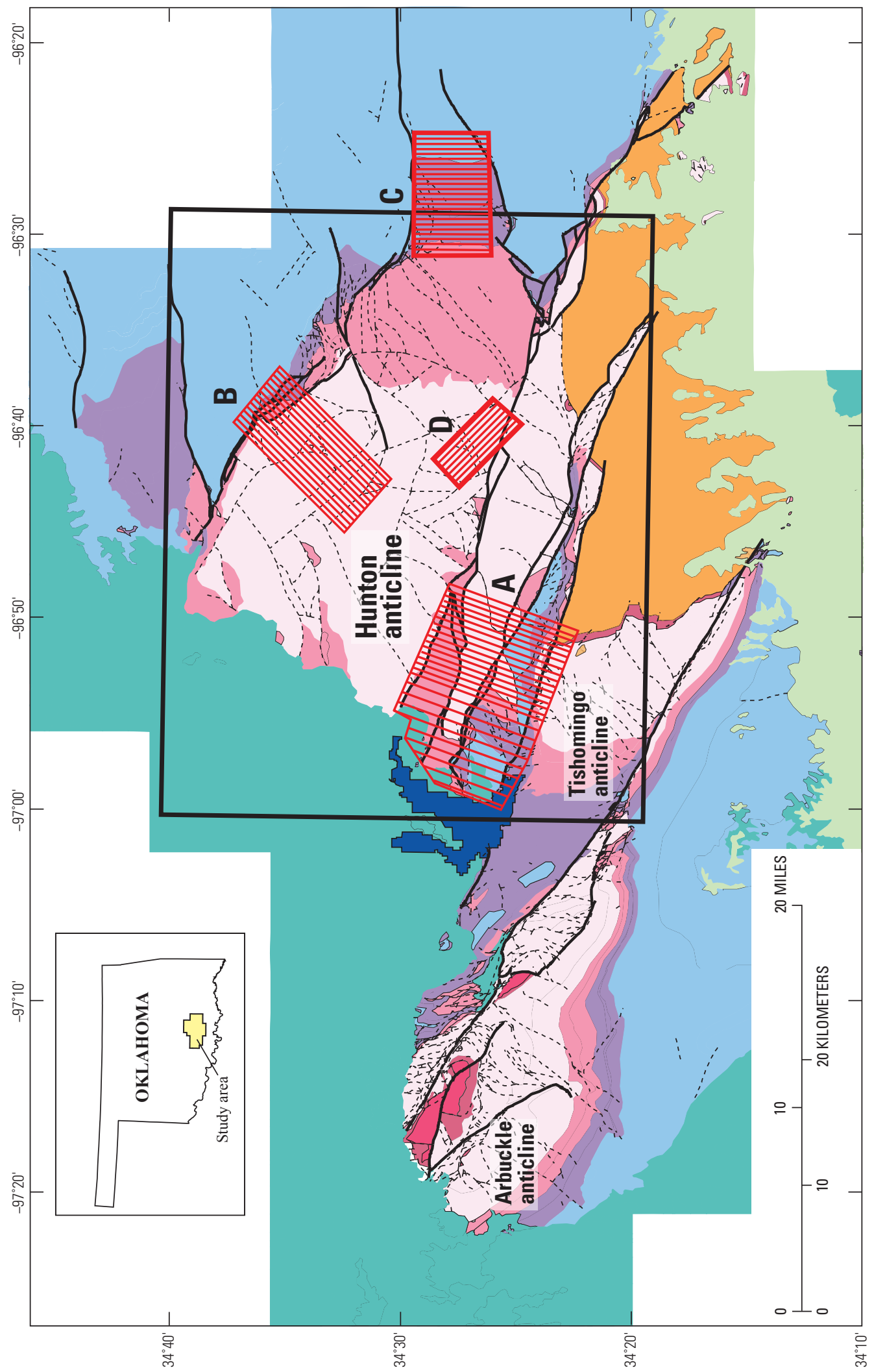

홍

言惫言

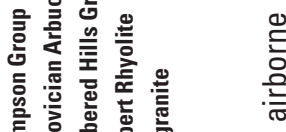

的部言总

兽

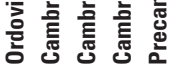

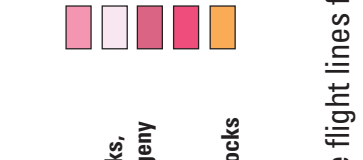

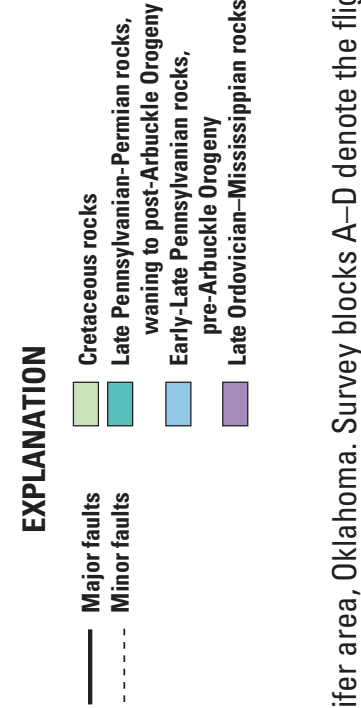

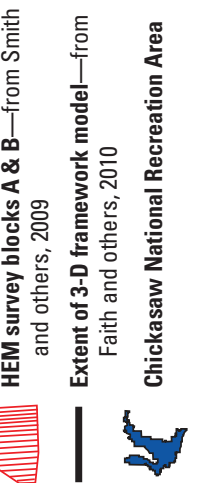

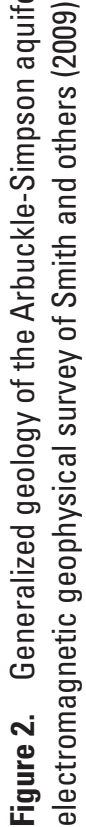


springs in the west. An experimental waterborne electromagnetic (WEM) survey of the Lake of the Arbuckles was carried out in August, 2009, in a proof-of-principal application using a modified airborne bird on a towed raft to map sub-bottom geology (Blome and Smith, 2010). A previous seismic survey northeast of CNRA also showed that faults extend to basement to an estimated depth of 3,500 ft (Kennedy, 2008).

Another task of the NCGM project and the ArbuckleSimpson Hydrology Study was to construct a 3-D EV geologic framework model to accurately quantify the geometric relations between the stratigraphic units in the Hunton anticline area (table 1; fig. 2). This 3-D EV geologic framework model by Faith and others (2010) depicts the volumetric extent of the aquifer and provided the structure, hydrostratigraphic layer thickness, and elevation data needed to construct a MODFLOW regional groundwater flow model (fig. 3). Data from the geologic framework model included the elevations for the tops of four modeled hydrostratigraphic units: basement, Arbuckle-Timbered Hills Groups, Simpson Group, and postSimpson units (Christenson and others, 2011).

The National Park Service (NPS) held a Geologic Resources Evaluation (GRE) scoping meeting on October 17-18, 2007, at CNRA's Travertine Nature Center to discuss the potential for detailed (1:24,000-scale) geologic mapping of the Recreational Area and for conducting ground geophysical surveys in the northern part of the CNRA Travertine area where there is abundant spring discharge (Graham, 2008). Participants at the meeting included representatives from the GRE, USGS Oklahoma Water Science Center, USGS Geology and Environmental Change Science Center (Denver), OWRB, OGS, OSU, and Colorado State University (CSU). Maps of 1:24,000 scale (or larger) are useful to both CNRA and the NPS GRE because they capture most geologic features of interest and are spatially accurate to within $12 \mathrm{~m}$ (40 ft) (Graham, 2008; Blome and others, 2009). An NPS contract was awarded the USGS in 2008 to map the CNRA, also referred to informally as the Recreation Area in this report, at 1:24,000-scale and geologic mapping was carried out in 2009 through 2010. Reconnaissance geologic mapping in other areas of the Hunton anticline also began in 2009.

This report contains a geologic map sheet and a pamphlet that include stratigraphic and structural data for areas up to a few miles outside the CNRA. The map sheet includes a 1:24,000-scale geologic map and topographic and shaded relief data layers for the CNRA map area, as well as interpretive cross sections that depict subsurface structural and stratigraphic relations in those parts of the map area.

\section{Previous Geologic Mapping}

Taff (1903) and Bain and Taff (1904) produced the first geologic maps of the Arbuckle Mountains, both of which had a scale of 1:125,000 (fig. 1). The lithostratigraphic nomenclature of these early maps included many of the same or similar rock-unit names used today. Units included on these two maps were their "Reagan sandstone" (lowermost formation of the Timbered Hills Group today, that is exposed to the west and southeast of the mapped area), "Arbuckle limestone" (now considered to be the Arbuckle Group), "Simpson formation" (now considered to be the Simpson Group), and the "Viola limestone" (currently known as the Viola Group). The Taff (1903) map was reprinted by the Oklahoma Geological Survey with some minor changes (Taff, 1928).

Geologic mapping of the Arbuckle Mountains surged in the 1940s and 1950s with studies led by W.E. Ham. The first 1:72,000-scale map of the geology of the Arbuckle Mountains area was by Ham and others (1954). This map is considered by many to be the most accurate geologic map of the Arbuckle region. The Ham and others (1954) map was later included in an Oklahoma Geological Survey guidebook by Ham (1955). Ken S. Johnson later revised the Ham and others (1954) geologic map as Johnson (1990) and Fairchild and others (1990) included Johnson's revision of the Ham and others (1954) map in an Oklahoma Geological Survey Circular on the hydrology of the Arbuckle Mountains. Both the 1954 and revised 1990 map were published twice; only the latter publications are accessible.

The first digital map coverage of the Arbuckle Mountains, which included the area of the CNRA mapping effort, was the geospatial map database constructed by Cederstrand (1996). Cedarstrand's (1996) map was digitized from the 1:250,000scale Hydrologic Atlas map 3 of Hart (1974). The small scale of Cederstrand's (1996) digital map and the fact that it doesn't include attitudes (strikes and dips) or Quaternary deposits, made it of limited use in our construction of a 1:24,000-scale geologic map of CNRA. Our comparison of Cederstand's digital geologic map (1:250,000 scale) with the larger scale maps of Ham and others (1954; 1:72,000 scale) and Johnson (1990; 1:100,000 scale) showed location discrepancies of 200 $\mathrm{m}(656 \mathrm{ft})$ in many areas and up to $400 \mathrm{~m}(1,312 \mathrm{ft})$ locally. These location discrepancies likely reflect the diminished accuracy inherent in the smaller scale of the Cederstrand (1966) map. The digital geologic map databases by Heran (2003) and Stoeser (2007), of Oklahoma and the central U.S. States respectively, are at 1:500,000-scale and too small a scale to help in constructing a large-scale geologic map of CNRA. We scanned and registered the larger scale, more accurate, geologic maps of Ham and others (1954) and Johnson (1990), and they proved useful in our mapping and compilation.

\section{Geologic Setting}

The depositional and structural evolution of CNRA, and the larger region of the Arbuckle Mountains, can be characterized by four phases of sedimentation, tectonics, and erosion that include: (1) a rifting phase during Early and Middle Cambrian time, which was marked by the development of marginal faults and igneous activity; (2) a deposition and subsidence phase during Late Cambrian through Middle Mississippian time, when a thick sequence of shallow marine sediments 


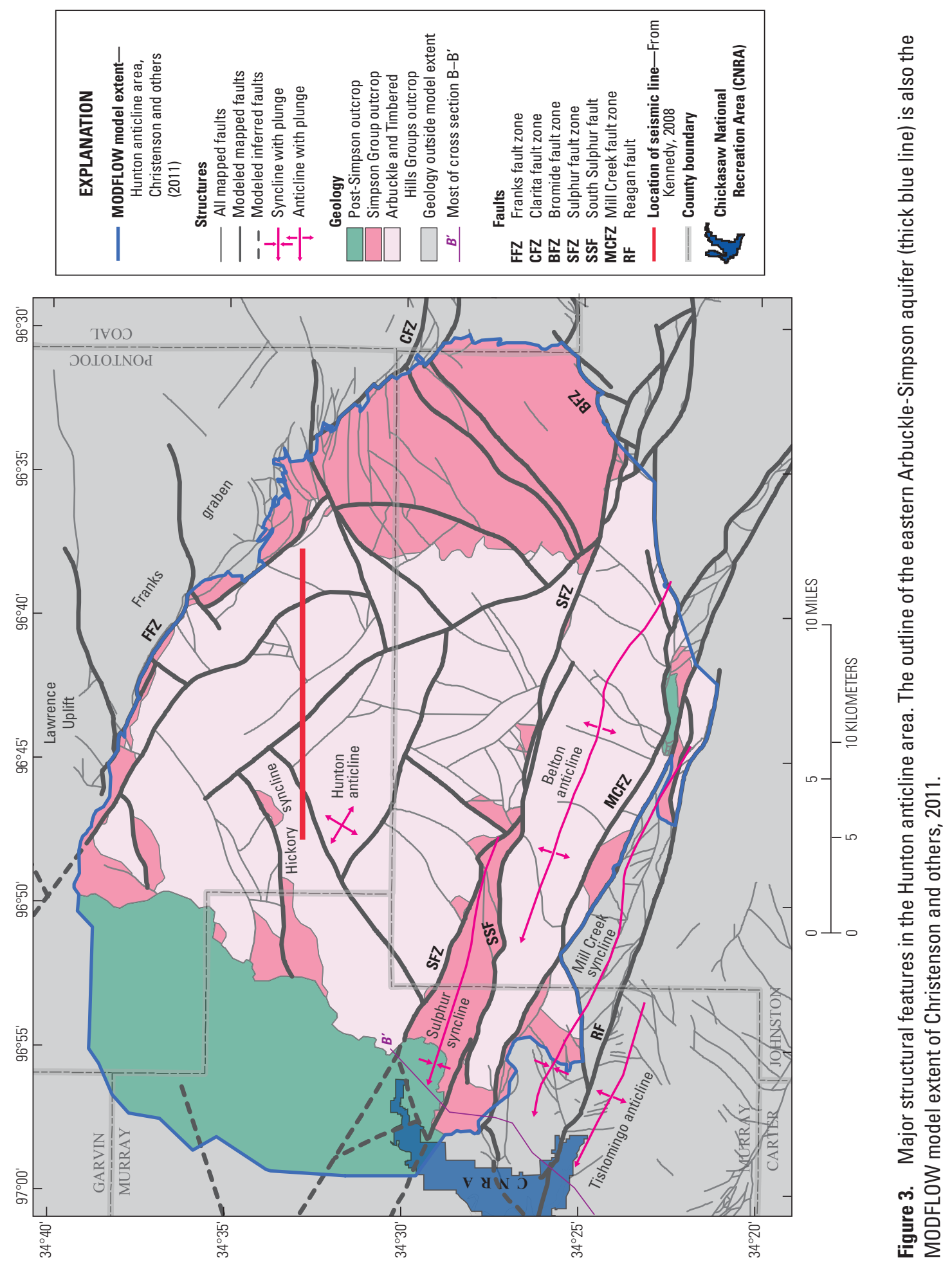


accumulated along the continental margin and a much thicker sequence accumulated in the subsiding basin; (3) an uplift and deformation phase during Pennsylvanian time, marked by intense folding and faulting; and (4) a phase of major erosion, which in combination with post-Pennsylvanian tilting and minor faulting, resulted in southeast-trending streams and peneplanation of the Arbuckle Mountains (Christenson and others, 2011).

\section{Stratigraphy}

The Arbuckle Mountains consist of folded and faulted Precambrian and Cambrian igneous rocks and Paleozoic sedimentary rocks ranging in age from Cambrian through Late Pennsylvanian. These older and more deformed rocks of the Arbuckle Mountains are covered on the east, north, and west by gently westward-dipping younger strata of Late Pennsylvanian and Permian age, and on the south by gently southwarddipping Early Cretaceous rocks.

During Cambrian time, continental rifting occurred in the Ouachita orogenic belt in southern Oklahoma and thick successions of limestone and dolomite, along with minor quartz sandstone, accumulated in the rift basin. During Mississippian and Pennsylvanian time, continental collision on the eastern and southern U.S. margins with Africa and South America, respectively, created the ancestral Ouachita Mountains that include the highly folded and faulted Arbuckle Mountains. This collision also caused uplift on the craton side of the ranges forming the Ozark uplift of Missouri and the Llano uplift of central Texas. The Anadarko Basin, positioned north and west of the Arbuckle-Wichita trend, subsided during the late Paleozoic and contains the greatest thickness of Paleozoic sedimentary sequences in the region (Donovan, 1995; Keller and Baldridge, 1995).

The lithostratigraphic units in CNRA are all Paleozoic in age, with the exception of artificial fill along the Lake of the Arbuckles dam site and thin Quaternary deposits exposed along the rivers and streams. The Paleozoic rocks include the upper part of the Arbuckle Group, the Simpson Group, numerous post-Simpson rock units, and the Pontotoc Group, that collectively range in age from the Early Ordovician to Permian (table 1). Unfortunately, due to dense vegetation and subtle topography, many of these units are poorly exposed.

Adjacent to the CNRA map area, in areas extending to the west and southeast, some older rock units are exposed. These older units include the middle and lower parts of the Arbuckle Group and relatively thin exposures of the Cambrian-age Timbered Hills Group (Reagan Sandstone and overlying Honey Creek Formation) that unconformably overlie Proterozoic-age granitic basement rocks. The Reagan Sandstone is a Paleozoic, transgressive sandstone that lies directly on Precambrian basement rocks and its composition and texture vary markedly. For example, the Reagan Sandstone can either be quartzose, arkosic, or glauconitic and it ranges texturally from fine- to very coarse-grained. The younger Honey Creek Formation is a sandy, dolomitic limestone that is overlain by the lower, middle, and upper parts of the Arbuckle Group containing limestone, dolomite, and thin sandstones. The Timbered Hills Group is the oldest rock unit containing the Arbuckle-Simpson aquifer, and together with the overlying Arbuckle and Simpson Groups, form the hydrostratigraphic units of the ArbuckleSimpson aquifer (Faith and others, 2010).

The oldest rock units in the CNRA map area are a thick sequence of carbonate rocks assignable to the Arbuckle Group of Late Cambrian to Early Ordovician age. Arbuckle Group sequences that outcrop mostly northeast, southeast, and southwest of the CNRA map area are more complete. Arbuckle Group exposures within CNRA and nearby areas are generally identified as belonging to the Lower Ordovician West Spring Creek Formation (map unit Ow), which is the uppermost Arbuckle Group unit. In some areas lacking key marker beds, this unit is included in the West Spring Creek and Kindblade Formations, undifferentiated map unit (Owk). Both the West Spring Creek and underlying Kindblade Formations are Early Ordovician in age. Because the entire Arbuckle Group is not exposed and has not been penetrated by drilling in the CNRA map area, Arbuckle Group thickness beneath CNRA is unknown (Barthel 1985; Hanson and Cates 1994). However, a well drilled for oil exploration, located northeast of CNRA in the Lawrence uplift (fig. 3), penetrated the entire Arbuckle Group. The total thickness of the Arbuckle Group in this well is 3,095 ft (940 m) (Puckett and others, 2009). West of the map area, in the Arbuckle anticline area (fig. 2), the Arbuckle Group is about 6,700 ft (2,042 m) thick (Fey, 1989). The Arbuckle Group is the middle part of the sequence of rock units that contain the Arbuckle-Simpson aquifer.

In other parts of the Arbuckle Mountains, the Arbuckle Group has locally been differentiated into eight formations based on lithostratigraphy and biostratigraphy (Fay, 1989). These formations are, in ascending stratigraphic order: the Fort Sill Limestone, Royer Dolomite, Signal Mountain Formation, Butterly Dolomite, and the McKenzie Hill, Cool Creek, Kindblade, and West Spring Creek Formations. Detailed lithologic descriptions for many of these formations are based on the excellent sections exposed during the construction of U.S. Interstate 35 through the Arbuckle Mountains (Fay, 1989), west of CNRA in the Arbuckle anticline area (fig. 2). Identifying the individual Arbuckle Group formations in the subsurface using well logs is difficult due to the scarcity of drill holes that penetrate the entire Arbuckle Group and the pervasive dolomitization (for example, in the Hunton anticline area) that masks the original depositional textures of these formations (Faith and others, 2010).

The Simpson Group of Middle Ordovician age is the youngest geologic unit containing the Arbuckle-Simpson aquifer. The Simpson Group is up to $1,000 \mathrm{ft}(305 \mathrm{~m})$ thick east of CNRA in the eastern parts of the Hunton anticline area (Faith and others, 2010), about 2,300 ft (700 m) thick west of the map area in the Arbuckle anticline, and about 1,800-2,000 ft (550-610 m) thick in the CNRA map area. Simpson Group rocks are exposed along the margins of the Hunton anticline and in structurally low areas, such as the Sulphur syncline 
Table 1. Comparison of time-stratigraphic, lithostratigraphic, and hydrostratigraphic units exposed in Chickasaw National Recreation Map Area and their correlation with North American geologic stages.

\begin{tabular}{|c|c|c|c|c|c|c|c|}
\hline $\begin{array}{c}\text { Time-stratigraphic } \\
\text { unit }\end{array}$ & \multicolumn{3}{|c|}{ Stratigraphic unit } & \multicolumn{2}{|c|}{$\begin{array}{l}\text { Map } \\
\text { unit }\end{array}$} & $\begin{array}{l}\text { Aquifer } \\
\text { unit }\end{array}$ & $\begin{array}{l}\text { North } \\
\text { American } \\
\text { Stages }\end{array}$ \\
\hline Quaternary & \multicolumn{3}{|c|}{ Alluvium and Colluvium } & \multicolumn{2}{|c|}{ Qac } & Unconsolidated & \\
\hline Permian & \multirow{3}{*}{ Pontotoc Group } & \multicolumn{2}{|c|}{ Stratford Formation } & \multicolumn{2}{|c|}{ Ps } & \multirow{13}{*}{$\begin{array}{c}\text { Upper } \\
\text { confining } \\
\text { unit }\end{array}$} & \\
\hline \multirow{5}{*}{ Pennsylvanian } & & Vanoss & $\begin{array}{l}\text { Vanoss shale } \\
\text { facies }\end{array}$ & $\mathbb{P}$ & & & \multirow{2}{*}{ Virgilian } \\
\hline & & & $\begin{array}{l}\text { Vanoss Limestone } \\
\text { conglomerate facies }\end{array}$ & \multicolumn{2}{|c|}{ Pvc } & & \\
\hline & \multicolumn{3}{|c|}{ Deese Group } & \multicolumn{2}{|c|}{$\mathbb{P d}$} & & Desmoinesian \\
\hline & \multirow{2}{*}{\multicolumn{3}{|c|}{ Atoka and Wapanucka Formations }} & \multicolumn{2}{|c|}{ Paw } & & Atokan \\
\hline & & & & & & & Morrowan \\
\hline \multirow{3}{*}{ Mississippian } & \multicolumn{3}{|c|}{ Springer Formation } & \multicolumn{2}{|c|}{ PMs } & & \\
\hline & \multicolumn{3}{|c|}{ Caney Shale } & \multicolumn{2}{|c|}{ Mc } & & \\
\hline & \multicolumn{3}{|c|}{$\begin{array}{c}\text { Sycamore Limestone, Welden Limestone, } \\
\text { and Woodford Shale }\end{array}$} & \multicolumn{2}{|c|}{ MDsw } & & Kinderhookian \\
\hline Devonian & \multirow{2}{*}{ Hunton Group } & \multicolumn{2}{|c|}{ Upper part } & \multirow{2}{*}{ DSOh } & Dhu & & \\
\hline Silurian & & & ver part & & SOhl & & \\
\hline \multirow[t]{2}{*}{ Upper Ordovician } & \multirow{2}{*}{$\begin{array}{l}\text { Sylvan Shale and } \\
\text { Viola Group }\end{array}$} & & an Shale & \multirow{2}{*}{ Osv } & Os & & \multirow{2}{*}{ Cincinnatian } \\
\hline & & & a Group & & Ov & & \\
\hline \multirow{2}{*}{ Middle Ordovician } & \multirow{2}{*}{ Simpson Group } & $\begin{array}{l}\text { Bromide } \\
\text { McL }\end{array}$ & $\begin{array}{l}\text { ulip Creek, and } \\
\text { Formations }\end{array}$ & \multicolumn{2}{|c|}{$\mathrm{Obm}$} & \multirow{4}{*}{$\begin{array}{l}\text { Arbuckle- } \\
\text { Simpson } \\
\text { aquifer }\end{array}$} & \\
\hline & & Oil Creek a & Joins Formations & $\mathrm{O}$ & & & \\
\hline \multirow{2}{*}{ Lower Ordovician } & \multirow{2}{*}{$\begin{array}{l}\text { Arbuckle Group } \\
\text { (Upper part) }\end{array}$} & \multirow{2}{*}{$\begin{array}{l}\text { West Spring } \\
\text { Creek and } \\
\text { Kindblade } \\
\text { Formations }\end{array}$} & $\begin{array}{l}\text { West Spring } \\
\text { Creek Formation }\end{array}$ & Ouk & Ow & & \\
\hline & & & $\begin{array}{l}\text { Kindblade } \\
\text { Formation }\end{array}$ & & & & \\
\hline
\end{tabular}


(fig. 3). Simpson Group units are also eroded over structural highs, such as the Belton anticline (Ham, 1973).

The Simpson Group consists of, in ascending stratigraphic order: the Joins, Oil Creek, McLish, Tulip Creek, and Bromide Formations. However, in CNRA and surrounding areas only two undifferentiated Simpson Group map units are commonly mapped. The Oil Creek and Joins Formations are combined as one map unit (unit Ooj; table 1).This unit is characterized by a quartz-arenite sandstone (basal sandstone of the Oil Creek Formation, fig. $4 A$ ) that is both underlain and overlain by limestone and interbedded shale, and some thin sandstone beds also occur in the upper part of this map unit. The other undifferentiated Simpson Group map unit (unit Obm; table 1) includes the Bromide, Tulip Creek, and McLish Formations. This undifferentiated unit is characterized by alternating sandstone, green shale, and limestone (fig. 4B).

Post-Simpson units (rocks younger than the Simpson Group) mapped in and around CNRA, include the Upper Ordovician Viola Group and Sylvan Shale, the Upper Ordovician to Devonian Hunton Group, the Devonian to Mississippian Woodford Shale and Welden and Sycamore Limestones (mapped as one undifferentiated rock unit, MDsw), the Upper Mississippian Caney Shale, the Upper Mississippian to Lower Pennsylvanian Springer Formation, the undifferentiated, Pennsylvanian-age Atoka and Wapanucka Formations, the Middle Pennsylvanian Deese Group, the Upper Pennsylvanian Vanoss Formation, and the Lower Permian Stratford Formation (table 1). Characteristics and ages of the post-Simpson map units in and around CNRA are discussed in detail below and in the Description of Map Units.

Small outcrops of Upper Ordovician rocks of the Sylvan Shale and Viola Group occur in CNRA's Rock Creek area (fig. 1), as well as east and south of CNRA. Generally, these two units are mapped as one undifferentiated unit, Osv. However, in the south-central part of the map area, south of the Lake of the Arbuckles, the Viola Group (unit Ov) is mapped separately from the Sylvan Shale (unit Os) due to the good exposures. Figure $4 C$ shows a blocky, cherty Viola Group outcrop (unit Ov), located south of the Lake of the Arbuckles (fig. 1).

The Recreation Area contains discontinuous sections of limestone and marls belonging to the Upper Ordovician to Lower Devonian Hunton Group. This group includes as many as seven thin formations, of which six are present in the map area. Throughout much of the map area, the Hunton Group is poorly exposed and can only be mapped as one undifferentiated rock unit (unit DSOh). There is, however, one area south of the Lake of the Arbuckles where the Hunton Group is better exposed and, in that area, we mapped the upper part of the Hunton Group (Dhu) separately from the lower part of the Hunton Group (unit SOhl). The lower Hunton Group is glauconitic/oolitic recrystallized limestone (fig. $4 D$ ), overlain by dark-colored, thin-bedded, fossiliferous limestone with argillaceous limestone and minor shale; the upper $50 \mathrm{ft}(15 \mathrm{~m})$ contains light-colored argillaceous limestone. Upper Hunton
Group exposures are more clay-rich and are typified by alternating shale and thin-bedded, argillaceous limestone that weather to yellowish to tan mudstone (fig. $4 E$ ). These lithologies are overlain by thin-bedded limestone (fig. $4 F$ ) interbedded with sparse shale and cherty and marly lentils. Nodular cherty concretions also occur in the upper part of this unit and commonly contain numerous fossils (Amsden, 1957), some of which are silicified.

The Devonian to Mississippian Woodford Shale and Mississippian Sycamore Limestone are mapped as one undifferentiated unit throughout the CNRA map area (unit MDsw), as the contact between the two units is rarely observed. Although the Welden Limestone has been reported to outcrop between the Woodford Shale and the Sycamore Limestone, it is either missing or thinly exposed $(<7 \mathrm{ft}$ or $2 \mathrm{~m}$ ) in the map area. Exposures typical of the Sycamore Limestone contain shale and argillaceous, cherty, and silty limestone overlain by shale and marly limestone. Typical Woodford Shale exposures (fig. 5A) are characterized by dark- to light-gray, fissile shale, siliceous shale, bedded chert, and black bituminous shale. Locally, siliceous shale and bedded chert make up the largest parts of the Woodford Shale exposures.

Well-defined outcrops of the Middle to Upper Mississippian Caney Shale (Mc), are restricted to roadcuts and deeplyincised stream banks due to its fissile and friable lithology. Because of its friable nature, most Caney exposures occur as lush, grassy fields and slopes. Where the Caney Shale is well exposed (fig. $5 B$ ), it is typically characterized by dark-gray to black, laminated, fissile and friable shale, with both septarian and (or) phosphatic concretions of variable size.

The Caney Shale is overlain by a sequence of Upper Mississippian to Permian age that include the Upper Mississippian to Lower Pennsylvanian Springer Formation (Pms), the Lower to Middle Pennsylvanian Wapanucka Formation and Middle Pennsylvanian Atoka Formation (mapped as one undifferentiated rock unit, $\mathrm{Paw}$ ), the Middle Pennsylvanian Deese Group ( $\mathbb{P d}$ ), the limestone conglomerate and shale facies of the Upper Pennsylvanian Vanoss Formation (units Pvc and Pvs, respectively), and the Lower Permian Stratford Formation (unit Ps, table 1). These post-Simpson Group rock units are laterally discontinuous in the map area and to the east throughout the Hunton anticline area. Both the Deese Group and Vanoss Formation are conglomeratic (principally limestone conglomerate) and overlie major angular unconformities related to Pennsylvanian-age deformation of the Arbuckle Mountains.

The Springer Formation (PMs) crops out along the eastern periphery of the Recreation Area, but is only locally well-exposed along the banks of some drainages. The Springer Formation shale can contain sideritic, ferruginous, and calcareous concretions, and commonly includes thin beds of sandstone and limestone (fig. 5C). Locally, the sandstone beds can be up to tens of feet thick.

The Wapanucka and Atoka Formations are mapped together as one undifferentiated unit (Paw) in the CNRA 


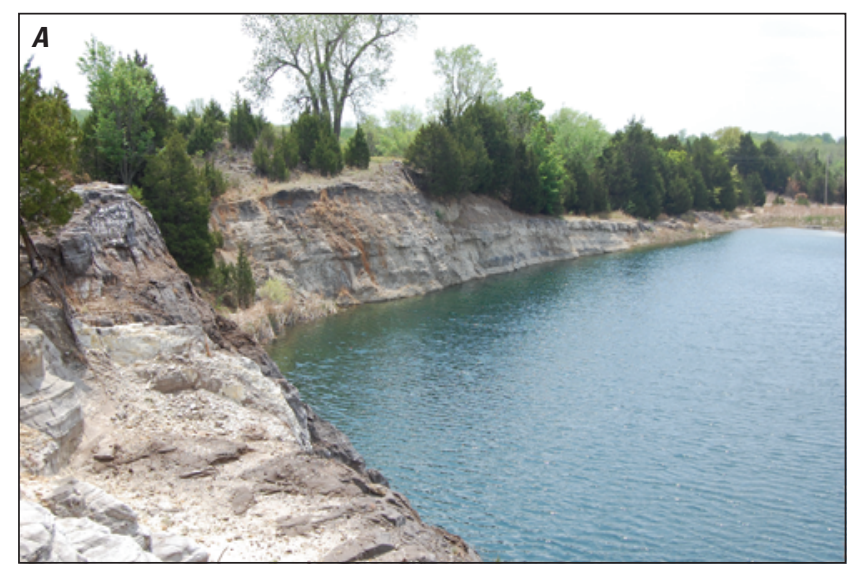

Oil Creek and Joins Formation (Ooj)

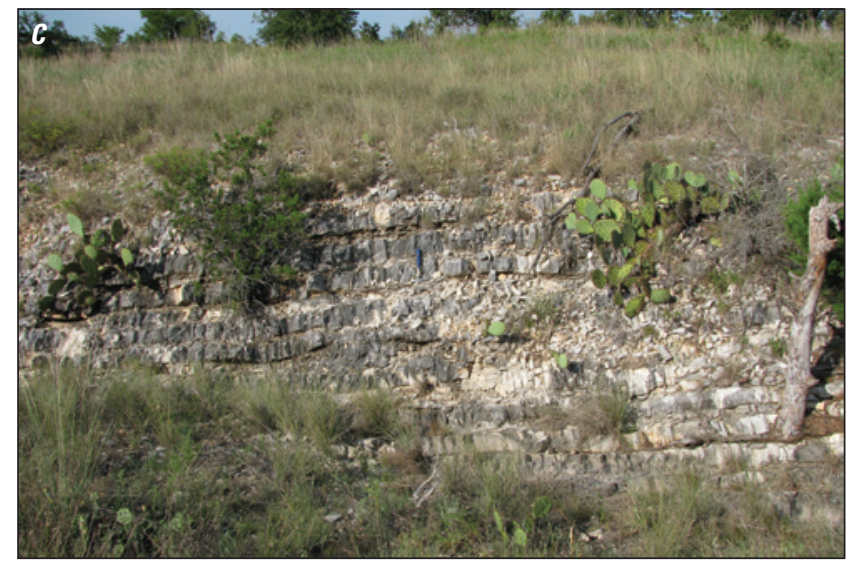

Viola Group (Ov)

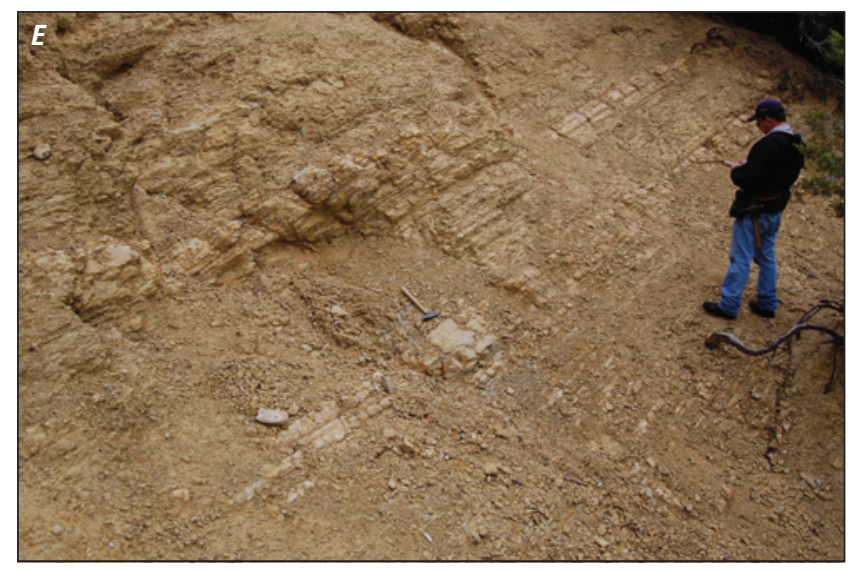

Upper Hunton Group (Dhu, Haragan Formation)

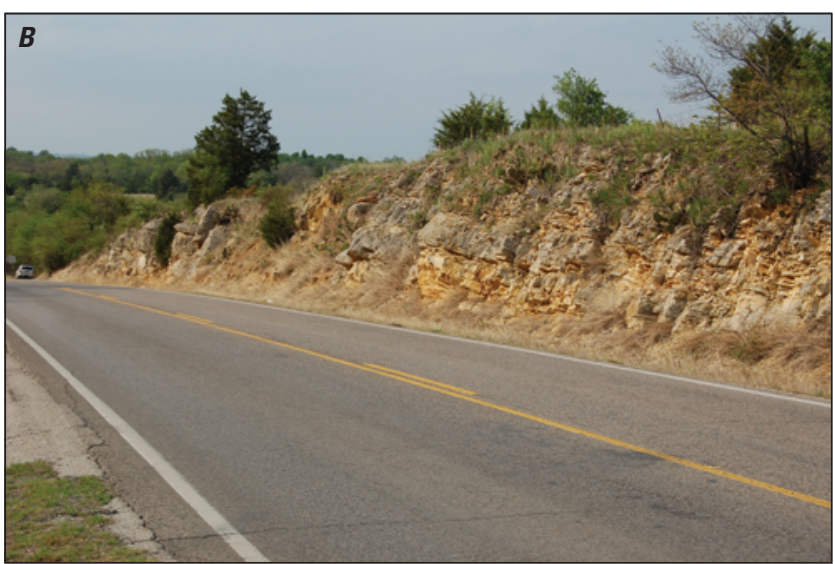

Exposure of Obm along U.S. Hwy 177 south of CNRA (Bromide Formation)

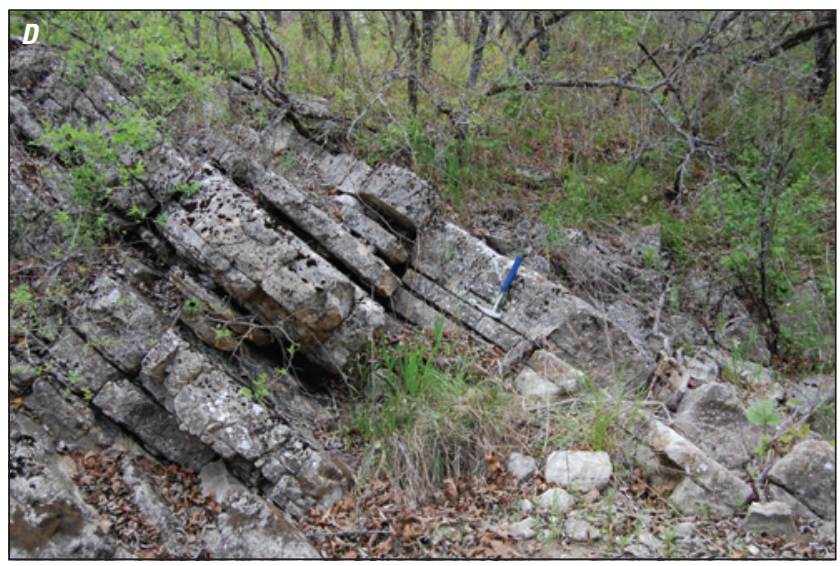

Lower Hunton Group (SOhl, Cochrane Formation)

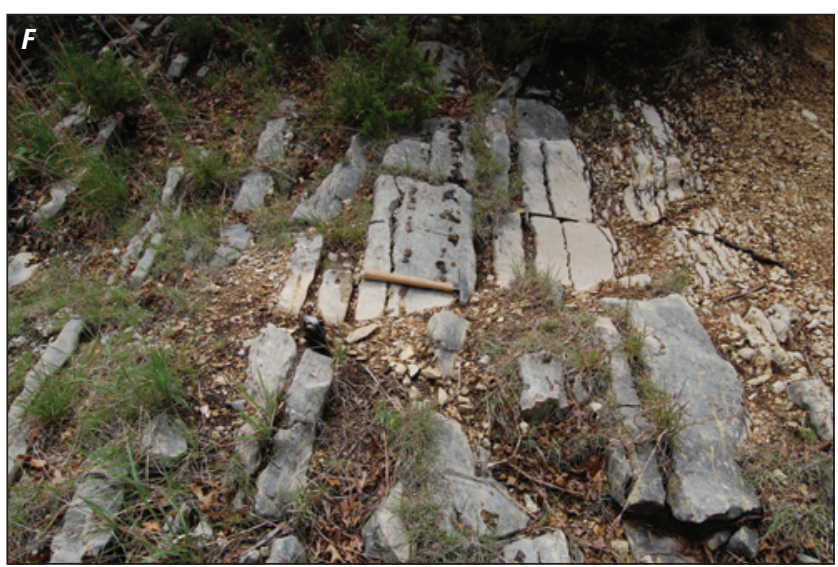

Upper Hunton Group (Dhu, Bois d'Arc Formation)

Figure 4. Photographs of Ordovician to Devonian units exposed in and nearby Chickasaw National Recreation Area. 


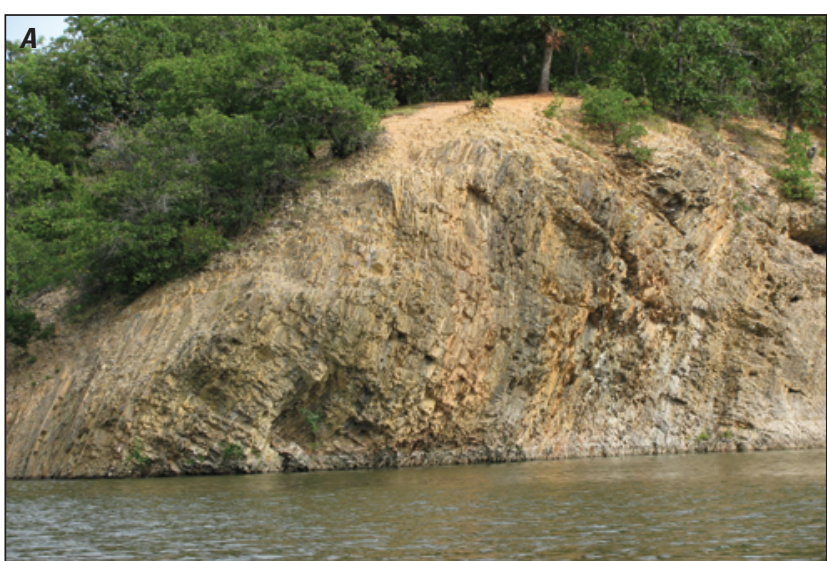

Woodford Shale (MDsw)

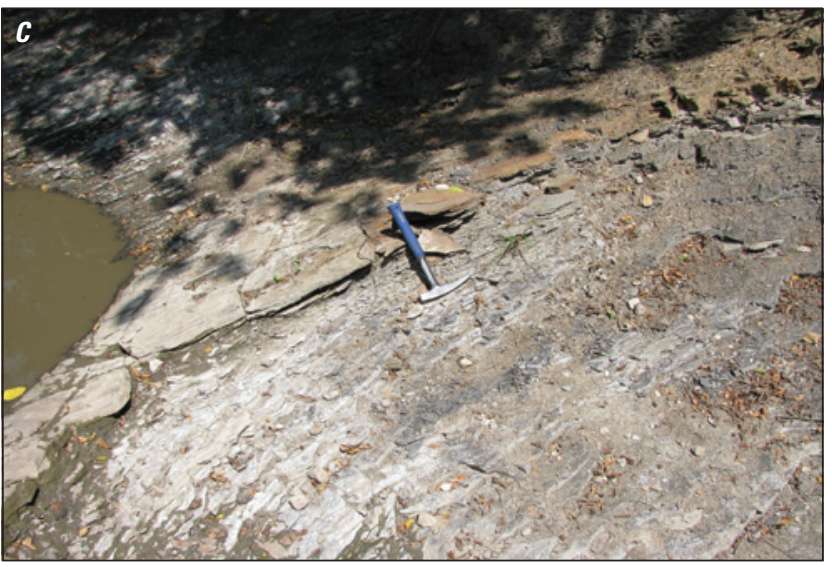

Springer Formation shale (PMs)

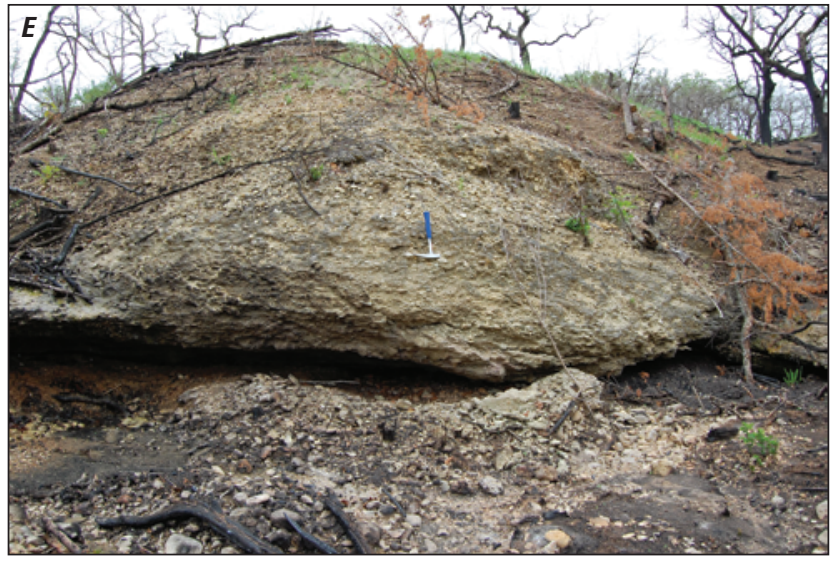

Limestone pebble conglomerate, Vanoss Formation (Pvc)

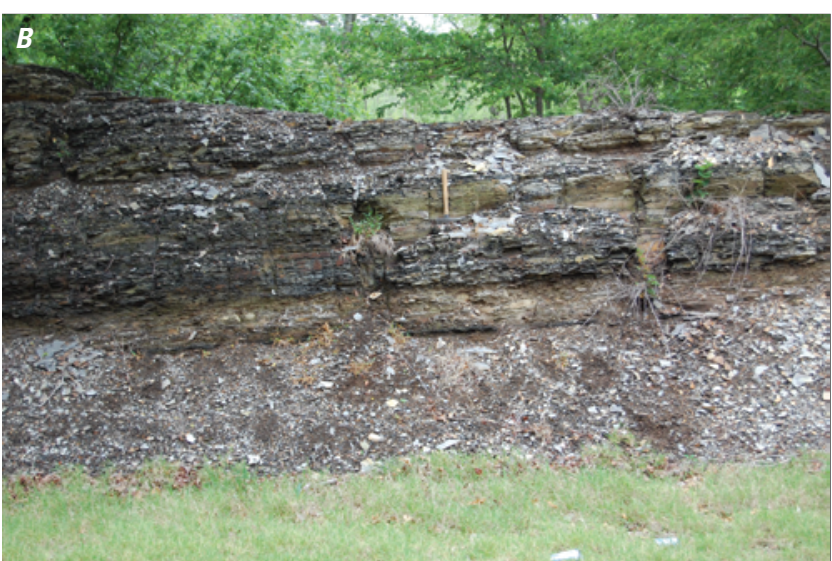

Caney Shale (Mc)

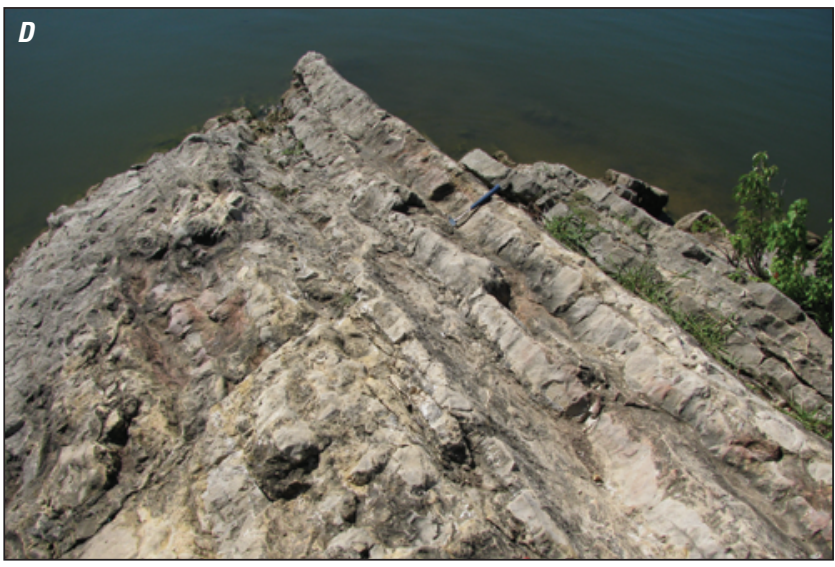

Deese Group limestone (Pd)

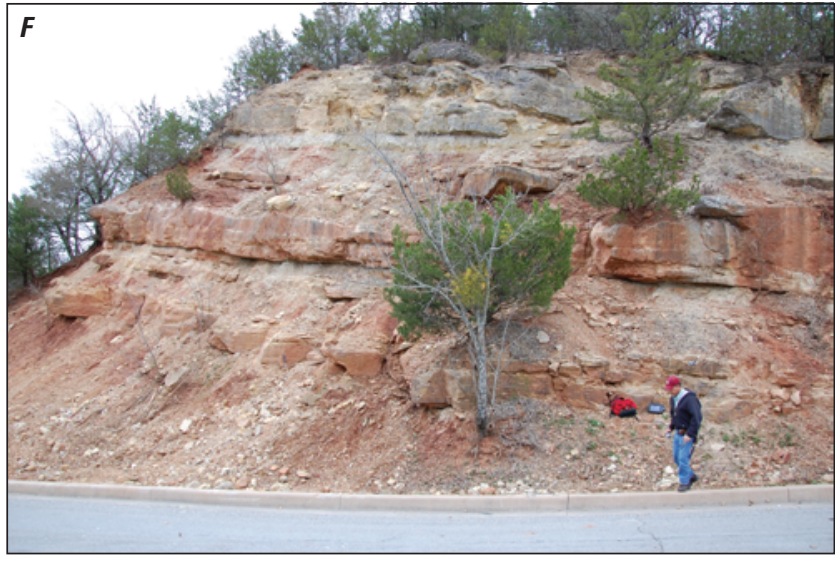

Massive sandstone, Vanoss Formation (Pvs)

Figure 5. Photographs of Devonian, Mississippian, and Pennsylvanian units exposed in and nearby Chickasaw National Recreation Area. 
map area and only occur within a fault-bounded wedge in the southeastern part of the map area (map sheet). Typically, this unit is white, massive limestone at its base overlain by shale and sandstone with some sandy limestone.

The Deese Group (unit $\mathbf{P d}$ ) outcrops in the east-central to southeastern part of the map area within the Mill Creek fault zone and in the fault block between this fault zone and the Reagan fault, farther south. Deese Group lithologies include massive sandstone, dark-gray and red shale, limestone conglomerate, and fossiliferous, light gray to white limestone (fig. 5D).

The Late Pennsylvanian-age Vanoss Formation is the principal rock unit exposed in the Recreation Area (Hanson and Cates 1994; Scheirer and Scheirer, 2006). It consists of a limestone conglomerate unit (Pvc) overlain by a shalerich unit (Pvs). Clasts in the Vanoss limestone conglomerate facies unit ( $\mathbb{P v c}$ ) include limestone and dolomite clasts eroded from the Simpson and Arbuckle Groups, along with some granitic clasts derived from underlying basement rocks. The Vanoss Formation has a maximum thickness of 650 feet (198 m) (Ham, 1973), and thickens from east to west in the northern part of the Recreation Area, commonly termed the Travertine District (Scheirer and Scheirer 2006). The Vanoss Formation has a near zero thickness near the Arbuckle-Simpson aquifer-bearing rock units in the eastern part of the map area, but the Vanoss is approximately $330 \mathrm{ft}(100 \mathrm{~m})$ thick along the northern border of CNRA in the Vendome well area (fig. 1). The unit's lower limestone conglomerate facies $(\mathbb{P v c})$, consists mainly of tightly cemented, well-rounded to subangular limestone and dolomite pebbles, cobbles, and small boulders, along with some clasts of sandstone, siltstone, shale, chert, granite, and gneiss (fig. $5 E$ ). The tightlycemented and relatively undeformed Vanoss limestone conglomerate facies unit (Pvc) acts as a confining layer where it overlies the deformed Arbuckle-Simpson aquifer units. The upper shale facies unit of the Vanoss Formation (Pvs), which overlies the limestone conglomerate facies, contains shale and sandstone beds and lentils (fig. 5F). All clastic strata in the shale facies unit are arkosic, with some of the sandstones so much so that they appear granitic. Arkosic material decreases upward in the shale facies unit as shale becomes more prominent.

The youngest Paleozoic unit in and around CNRA is the Early Permian age Stratford Formation (unit Ps), which conformably overlies the Vanoss Formation. The Stratford's basal Hart Limestone Member consists of a series of alternating limestone, shale, and sandstone sequences. Overlying the Hart Limestone Member is an undetermined thickness of dark-colored shale, with minor sandstone lentils, some of which are arkosic.

\section{Regional Structural Framework}

The principal structural features in the Arbuckle Mountains are northwest-southeast oriented faults and folds (fig. 3). These major faults and folds of the Arbuckle
Mountains are Pennsylvanian in age and result from orogenic events that occurred along the southern margin of North America (Ham, 1973; Cardott and Chaplin, 1993). Currently, the most widely accepted interpretation of these structures is that the folds and reverse/thrust fault offsets result from secondary northeast-southwest directed compression (transpression) related to primary left-lateral strike-slip along the major northwest-southeast striking faults (Tanner, 1963; Wickham, 1978; Marshak and others, 2003). There are others who argue that the evidence for major left-lateral slip along faults is poorly constrained and far less compelling than the evidence for northeast-southwest directed compression (for example, Brown, 1984; Naruk, 1994). The tectonic significance of these major structures of the Arbuckle Mountains will likely continue to be debated. The CNRA map area is in the north-central part of the Arbuckle Mountains and it includes several of the major northwest-southeast oriented folds and faults of the Arbuckle Mountains.

Pennsylvanian uplift and related folding and faulting of the Arbuckle Mountains is well constrained as the result of two main and distinct pulses of Pennsylvanian deformation that are commonly called the Wichita orogeny and Arbuckle orogeny (Ham, 1973; Allen, 2000). The earliest event, the Wichita Orogeny, mainly produced broad uplifts, or arches, in the region of the Arbuckle Mountains. Whereas deformation related to the younger Arbuckle orogeny was much more intense, it produced nearly all of the folding and faulting that is now preserved and expressed by the major northwestsoutheast oriented faults, folds, and subsidiary structures in the Arbuckle Mountains (Cardott and Chaplin, 1993). In the CNRA map area, the Deese Group and correlative units (Middle Pennsylvanian, Desmoinesian), and the Vanoss Formation (Late Pennsylvanian, Virgilian) overlie major angular unconformities related to these two orogenies and structural and stratigraphic relations of these units and their underlying unconformities constrain the timing and character of the Wichita and Arbuckle orogenies.

The Wichita orogeny was active in late Early to early Middle Pennsylvanian time. It produced tight folds and faults in the Criner Hills south of the Arbuckle Mountains and in the Wichita Mountains northwest of the Arbuckle Mountains (Allen, 2000). However, in the Arbuckle Mountains region this early orogeny produced very broad northwest-southeast oriented uplifts in the regions now occupied by the Hunton and Tishomingo anticlines (Cardott and Chaplin, 1993) (figs. 2 and 3). The resulting structural basin that formed between these two uplifts mostly coincides with the Mill Creek syncline fault block, and the Deese Group (Middle Pennsylvanian, Desmoinsian) that was deposited in this intervening basin during erosion of these uplifts. Desmoinsian age units correlative to the Deese Group, such as the Franks Conglomerate, were also deposited at this time along the northeastern flank of the ancient Hunton arch, which is also referred to as the Paul's Valley uplift (Allen, 2000) in the Franks graben area (fig. 3). Thousands of feet of strata were erosionally removed from the crest of these uplifts 
or broad arches during deposition of the Deese Group and Franks conglomerate. Where these Desmoinsian-age rock units overlap the flanks of these uplifts, they overlie a major angular unconformity that truncates more steeply dipping older rock units that were gently tilted during the Wichita orogeny. This major unconformity is commonly called the Wichita unconformity, and we show and label it as "WU" in cross section $B-B^{\prime}$ on the map sheet and figure 6 .

The angular nature of this Wichita unconformity is documented in outcrops, but perhaps is best shown in drillhole data from a transect of drill holes that trend northeast across the southwestern flank of the now buried northwestern continuation of the Hunton arch, located about 18 miles northeast of the map area. Allen (2000, his fig. 22) shows this northeast-trending transect of wells in a cross section that clearly shows that the Wichita unconformity and the overlying Deese Group truncate older rock units that dip gently to the southwest. In this cross section, the Wichita unconformity cuts across the gently southwest-dipping older rock units and the overlying Deese Group progressively overlies older erosionally truncated units from the southwest to the northeast. At the southwestern end of this transect, the Deese Group overlies the Caney Shale (Middle to Upper Mississippian), whereas about 8 to 9 miles to the northeast along this transect, the unconformity progressively cuts down section where the Deese Group overlies the Viola Group (Upper and Middle Ordovician). Similar to this transect, cross section $B-B^{\prime}$ also shows the Deese Group truncating older units from the southwest to northeast (see map sheet). The $B-B^{\prime}$ section extends through the Mill Creek syncline and farther northeast onto the southwest flank of the Hunton anticline, crossing a region that was part of the southwest flank of the ancient Hunton arch. Along $B-B^{\prime}$, in the Mill Creek syncline area, the Deese Group truncates Lower Pennsylvanian-Upper Mississippian rocks (Springer Formation), and in the Sulphur syncline area, the Deese Group truncates MississippianDevonian rock units.

The main and most intense period of deformation in the Arbuckle Mountains occurred during the Arbuckle orogeny that post-dates deposition of the Deese Group. The post-Deese Group age of the Arbuckle orogeny is established, both in the CNRA map area and elsewhere in the Arbuckle Mountains, on the fact that Deese Group strata are deformed (folded and faulted) equally with the underlying older rock units. The cessation of the Arbuckle orogeny is confined by the deposition of the Late Pennsylvanian (Virgilian) age Vanoss Formation. Although the Vanoss Formation is locally broadly warped, it truncates and buries the older folded and faulted rock units (Ham and others, 1954; Ham, 1973). This is particularly apparent throughout much of the northern part of the CNRA map area, where the faults, folds, and deformed older rock units all terminate at and are buried by the Vanoss Formation $\left(A-A^{\prime}, B-B^{\prime}\right.$ on map sheet, and fig. 6). The authors label and informally refer to the angular unconformity at the base of the Vanoss Formation as the Arbuckle unconformity (labeled "AU" in $A-A$ ', $B-B$ ' on map sheet, and fig. 6).

\section{Structural Features in the Chickasaw National Recreation Map Area}

As in other parts of the Arbuckle Mountains, the major structural features in the CNRA map area are northwestsoutheast oriented folds and faults (map sheet, fig. 6). The major northwest-southeast trending folds in the map area are the Hunton, Belton, Tishomingo, and Dougherty anticlines, and the Sulphur and Mill Creek synclines $\left(A-A^{\prime}, B-B^{\prime}\right.$, and fig. 6); other unnamed folds also occur in the southern part of the map area. The major northwest-southeast striking faults of the map area are the Sulphur, South Sulphur, Mill Creek, and Reagan faults or fault zones; other unnamed faults of various strike directions also occur in the map area. For the most part, the major faults cut and offset the folds and folded structural blocks defined by the major faults. Although the names of these regionally extensive, major faults and folds (fig. 3) have long been established (for example, Ham, 1945; Ham and others, 1954), some of the major fold names denote internally deformed, upthrown or downthrown fault blocks that are grossly anticlinal or synclinal in character.

Despite being termed the Mill Creek syncline and the Belton anticline in the map area, these regionally extensive structures represent internally faulted and folded fault blocks much more than they represent individual synclinal and anticlinal features. This is particularly true for the Mill Creek syncline that is a complexly folded and faulted graben-like (downthrown) fault block that occurs between the Mill Creek fault zone and the Reagan fault (fig. 6, $B$ - $B^{\prime}$ ). Similarly, the Belton anticline is an internally folded, horst-like (upthrown) fault block that occurs between the Mill Creek fault zone and the South Sulphur fault. Unlike a single anticline or syncline, these complexly deformed fault blocks lack a crest or trough that can be mapped as a defining axial trace of the structure. Consequently, it is not possible to show such an axial trace (fold axis) for the structural features termed the Mill Creek syncline and the Belton anticline on the geologic map.

Unlike the Mill Creek syncline and the Benton anticline, the Dougherty and Tishomingo anticlines in the southern part of the map area are clearly expressed in the field and in imagery as large, relatively simple anticlines (fig. 6). Consequently, fold axes of the Dougherty and Tishomingo anticlines are shown on the geologic map, as are the fold axes of some smaller, unnamed but well-expressed anticlines and synclines in the southern part of the map area. In the northeastern part of the map area, the inferred location of the buried fold axis of the Sulphur syncline is also shown on the geologic map.

The faults are, in general, poorly exposed and poorly expressed in modern day topography. Most of the major faults have characteristics that suggest dip direction and sense of offset, as do some of the subsidiary faults. Based on that evidence, thrust, normal, and oblique-slip faults are shown on the map and in the cross sections. However, the dip direction and sense of offset along some faults in the map area are poorly constrained or unknown; these faults are shown as generic faults on the geologic map. 
We constructed two northeasterly trending cross sections that depict structural and stratigraphic relations in the subsurface of the CNRA map area (see map sheet). The cross sections are based on: (1) relations shown on the geologic map, (2) drill-hole data (table 2 on map sheet), (3) down-plunge and along-strike projections of structural relations, and (4) the regional style of these and other structural features in the Arbuckle Mountains as documented in existing publications. Like most cross sections of structurally complex regions, there are aspects of the subsurface relations that, to varying degrees, are interpretive. The structural features mapped in the eastcentral to northeastern part of the map area are shown in cross section $B-B^{\prime}$. The westward continuations of these structures are buried and concealed beneath Upper Pennsylvanian Vanoss Formation strata in the northwestern part of the map area (map sheet, fig. 6).

The major structural features of the CNRA map area, their local and regional structural and stratigraphic relations, and their subsurface relations depicted in the cross sections, are discussed below from north to south across the map area.

The Hunton anticline (fig. 3) is a broad, northwest-southeast trending anticlinal fold that, in part, developed during the Wichita orogeny as an even broader uplift or arch. The Hunton arch was probably more extensive than what is preserved today as the Hunton anticline (see Regional Structural Framework section of this report). It was later modified by folding and faulting during the younger and more intense Arbuckle orogeny. Many of the folds and faults discussed below deformed parts of the Hunton arch and its descendent, the Hunton anticline. The structural feature now preserved as the Hunton anticline is cut on the east and northeast by the Clarita and Franks fault zones (CFZ and FFZ, respectively, fig. 3), and on the south by the Sulphur fault zone (SFZ; fig. 3). The Clarita and Franks fault zones are both composed of a series of high-angle, down-to-the-northeast faults. The southeastern flank of the Hunton anticline is cut by similar faults of the Bromide fault zone (BFZ, fig. 3) that are down-to-the-southeast. Strata of the Arbuckle and Simpson Groups are exposed in the central part of the Hunton anticline and dip gently beneath unconformably overlying Upper Pennsylvanian rock units (for example, Vanoss Formation) along its northwestern flank. Along its northeastern flank between the Clarita and Franks fault zones, strata of the Arbuckle and Simpson Groups dip northeastward beneath a faulted, but essentially normal, stratigraphic sequence of Ordovician-Middle Pennsylvanian units that define the steeply-dipping limb of the anticline. In contrast, the southern flank of the anticline is sharply cut by the Bromide and Sulphur fault zones (BFZ and SFZ, respectively; fig. 3). A small part of the southwestern flank of the Hunton anticline projects into that northeast corner of the map area where it is mostly buried by Upper Pennsylvanian Vanoss Formation strata as shown in cross section $B-B^{\prime}$.

The Sulphur fault zone (SFZ, fig. 3), which cuts and truncates the southern flank of the Hunton anticline, also projects into the northeast corner of the map area and is buried by Vanoss Formation strata (fig. 6, cross section
$\left.B-B^{\prime}\right)$. Directly east of the map area, the Sulphur fault has a very linear map trace, suggesting that it dips steeply. It also shows apparent down-to-the-southwest displacement that juxtaposes older Arbuckle strata of the Hunton anticline to the north against younger Simpson Group strata to the south (fig. 3). Farther east of the map area, the Sulphur fault zone appears to merge with the South Sulphur fault and changes to show down-to-the-northeast displacement (fig. 3). The most eastern extension of the Sulphur fault zone becomes even more broken and braided in character and includes a fault strand that is mapped as a major southwest-dipping thrust fault (Ham and others, 1954; Johnson, 1990). The orientations of fault planes of the Sulphur fault zone are, for the most part, poorly constrained. We show the buried trace of this fault in cross section $B-B^{\prime}$ as a steep, southwest-dipping normal fault. However, the complexities along strike of this fault zone mentioned above suggest that the fault zone might instead have reverse or strike-slip components or a combination of both.

The Sulphur syncline is wedged between the Sulphur fault zone and Hunton anticline to the north and the South Sulphur fault and Belton anticline to the south (fig. 3). As noted above, these two faults join east of the map area and the Sulphur syncline does not appear to continue eastward from that intersection (fig. 3). Preserved within the Sulphur syncline are rocks of the Simpson Group (see map sheet; figs. 3 and 6). Exposures of the Sulphur syncline also terminate directly east of CNRA in the map area where, like most of the structural features discussed here, the syncline is unconformably overlain and buried by the Upper Pennsylvanian Vanoss Formation. In the eastern part of the CNRA map area, the South Sulphur fault (SSF, fig. 3) branches and its southern strand bends to the south, appears to lose displacement, and terminates just east of CNRA (map sheet, fig. 6). Its northern and more linear strand continues northwestward in the map area and is eventually buried by younger Vanoss Formation strata in the eastern part of the map area. Gravity data (Scheirer and Scheirer, 2006) suggest that the northern segment of the South Sulphur fault extends through CNRA in the subsurface (modeled as inferred faults, dashed line, fig. 3). Well data used in the 3-D EV model (Faith and others, 2010) also suggest that farther north, the Sulphur fault zone (SFZ, fig. 3) extends westward in the subsurface just north of CNRA (fig. 3). Subsurface drill-hole data indicate that two cross faults connect, or are confined between, the South Sulphur fault and Sulphur fault zone in the subsurface in the vicinity of CNRA (fig. 3). Therefore, the Sulphur syncline may also continue farther west and be present in a graben in the subsurface beneath CNRA (Cates, 1989; Scheirer and Scheirer, 2006). Exposures in the CNRA map area indicate that the northern strand of the South Sulphur fault has a linear northwest-striking trace, shows relatively small down-to-the-north displacement, and truncates cross faults like those inferred in the subsurface. Its linear trace and gravity data (Scheirer and Scheirer, 2006) suggest it dips steeply. We show it as a steeply north-dipping normal fault in cross section $B-B^{\prime}$. 


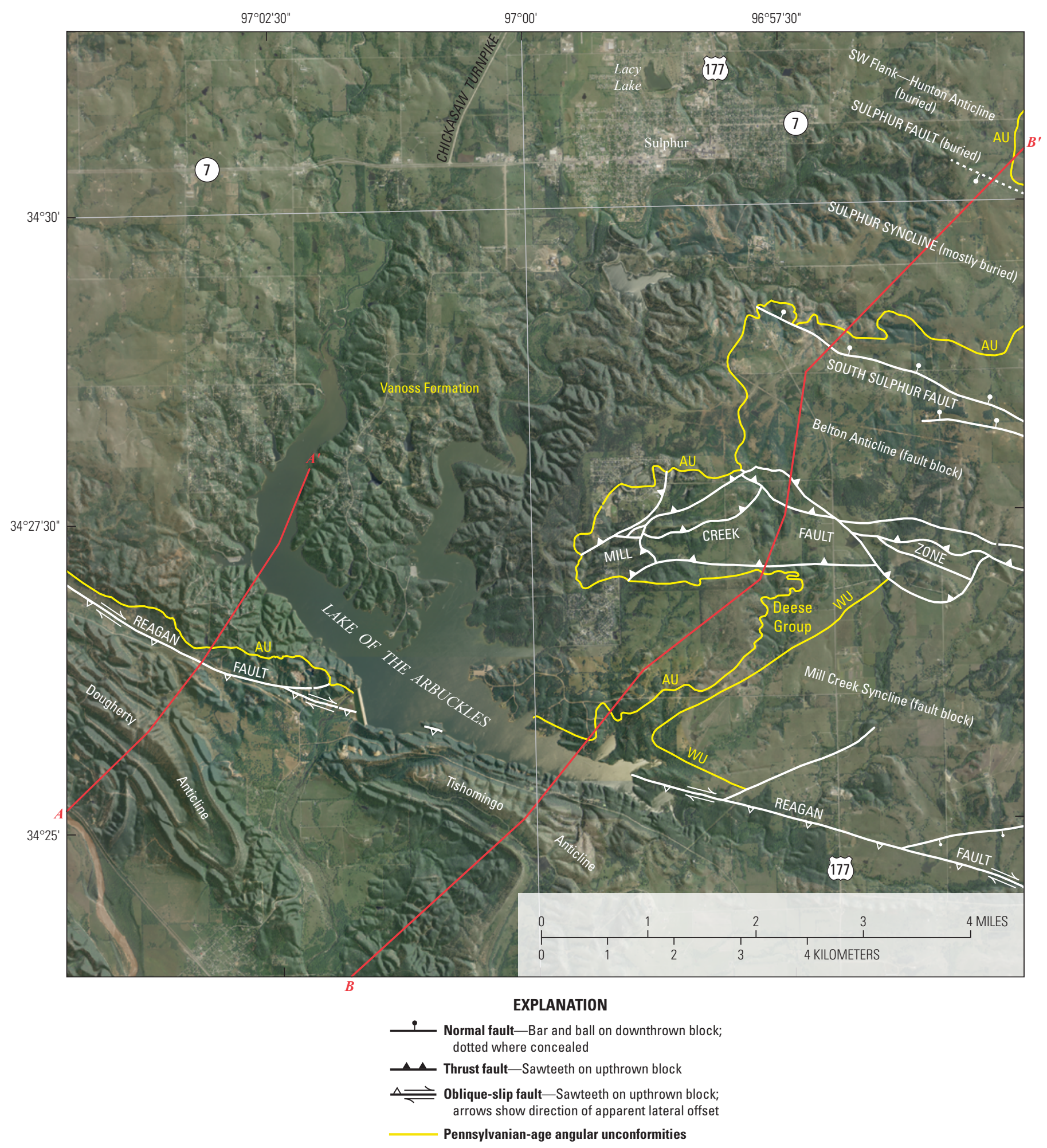

Figure 6. Map showing major structural features and related Pennsylvanian-age angular unconformities in and nearby the Chickasaw National Recreation Area. Major faults (thick white lines); major folds and folded fault blocks (white italic labels); major Pennsylvanian-age angular unconformities (thin yellow lines); WU, Wichita unconformity; AU, Arbuckle unconformity; lines of cross sections denoted as thin red lines. Base map is 2008 National Agricultural Imagery Program (NAIP) photography on shaded relief derived from 10-m digital elevation data (also shown on map sheet). 
The northwest plunging Belton anticline (fig. 3) occupies the northwest-oriented fault block that is bound to the north by the South Sulphur fault and farther east by the Sulphur fault zone; it is also bound to the south by the Mill Creek fault zone. In the map area, the Belton anticline exposes the Simpson Group and older underlying upper units of the Arbuckle Group. The rock units of this anticlinal feature are unconformably overlain and buried by the Vanoss Formation farther west in the map area. Off the map area, to the east and up plunge in the Belton anticline, older rock units of the middle part of the Arbuckle Group (Cool Creek and McKenzie Hill Formations) are exposed in the core of this anticlinally folded fault block (fig. 3). As shown in cross section $B-B^{\prime}$ and discussed below, structural relations of the Belton anticline and Mill Creek syncline fault blocks, and the Mill Creek fault zone that separates these blocks, are complex.

The Mill Creek fault zone (MCFZ, fig. 3) separates the Belton anticline fault block to the north from the Mill Creek syncline fault block to the south. Stratigraphic offset along the Mill Creek fault zone is estimated to be about 5,000 ft $(1,525 \mathrm{~m})$ down to the southwest, where Ordovician strata in the Belton anticline are juxtaposed against Pennsylvanian Deese Group strata in the Mill Creek syncline (Ham, 1945). In the eastern part of the CNRA map area, the Mill Creek fault zone is expressed as a complex braided system of faults (map sheet, fig. 6) that we map and interpret as a zone of northerly dipping thrust faults. The dip direction of some of these thrust faults had previously been presented as both south-dipping and north-dipping. Ham and others (1954) and Johnson (1990) showed the westernmost of these fault strands as south-dipping, north-directed thrust faults, whereas Williams (1983) incorporated drill-hole data in his map and cross sections of this area and showed them as north-dipping, south-directed thrust faults. In agreement with Williams (1983), Johnson and others (1984, their fig. 15) also show and discuss these faults as north-dipping, south directed thrusts. In the CNRA map area, strata in and along this fault zone are also locally overturned to the south, and east of the map area there is a syncline that is cut and overturned to the south along the fault zone (Ham and others, 1954; Johnson, 1990). Furthermore, along trend of the projection of this fault zone to the northwest, where the zone is likely buried in the subsurface beneath Vanoss Formation strata, drill-hole data show the presence of a syncline that is overturned to the south and cut by a northerly dipping thrust fault (Allen, 2000; his fig. 20). Oral communication with R.W. Allen (2012) suggests these structural relations in the subsurface probably mark the continuation of the Mill Creek fault zone in the subsurface northwest of the CNRA map area. Other regional tectonic maps also show that the Mill Creek fault zone is principally a north-dipping, south-directed zone of thrust/ reverse faults (for example, Jusczuk, 2002). Exposures of the Mill Creek faults are poor in the map area, but the traces of these faults suggest that they dip to the north. Collectively, these local and regional relations indicate that the Mill Creek fault zone is dominantly a south-verging system of thrust faults and related folds. Although the subsurface interpretation of this fault zone and related folds, shown in cross section $B-B^{\prime}$, is highly interpretive, it is based on the relations described above and explains the occurrence of an anomalous thrust slice of Deese Group within the Mill Creek fault zone.

The Mill Creek syncline lies directly south of the Mill Creek fault zone (figs. 3 and 6). As noted previously, the Mill Creek syncline is a complex graben-like fault block that, in part, preserves a remnant of a Desmoinsian-age basin that formed between the Tishomingo and Hunton uplifts during the Wichita orogeny (see Regional Structural Framework section of this report). That basin and these orogenic uplifts also predate most of the folding and faulting that is now preserved in the Arbuckle Mountains. The Middle Pennsylvanian (Desmoinsian) age Deese Group was deposited in this basin during erosion of the Wichita uplifts. The Deese Group also overlies the Wichita unconformity (WU, fig. 6) that is exposed in the Mill Creek syncline in the map area (map sheet; fig. 6) and overlies the Springer Formation (Upper Mississippian and Lower Pennsylvanian) along this unconformity. In cross section $B-B^{\prime}$, we show the Wichita unconformity (WU) in the subsurface of the Mill Creek syncline. We also infer that this unconformity is present in the subsurface farther to the northeast, where this Wichita-age unconformity gradually cuts across older units that had been gently tilted to the southwest along the southwestern flank of the Wichita-age Hunton arch (see Regional Structural Framework section of this report). The fault slice of the Deese Group in the Mill Creek fault zone (cross section $B-B^{\prime}$ ) implies that this unconformity is present in the subsurface of the Mill Creek fault zone region. We infer that this unconformity (WU), and the overlying Deese Group, are also present farther to the northeast where we show them buried beneath the Vanoss Formation in the core of the Sulphur syncline (see cross section $B-B^{\prime}$ ).

The Mill Creek syncline is now preserved as a narrow, northwest-trending graben-like feature, which is bounded on the north by the Mill Creek fault zone (MCFZ, fig. 3) and to the south by the Reagan fault (RF, fig. 3). East of the map area, these two faults join and Precambrian basement rocks outcrop east of that join and are cut by the fault zone (Ham and others, 1954; Johnson, 1990). This graben-like feature contains more than $8,000 \mathrm{ft}(2,440 \mathrm{~m})$ of broadly to tightly folded and faulted Paleozoic strata. The Deese Group is the youngest unit that is deformed in the Mill Creek syncline, and it and older units deformed in this feature are disconformably overlain and buried by Vanoss Formation strata in the eastern part of the map area. On the basis of evidence discussed above for displacement relations along the Mill Creek fault zone and for the Reagan fault discussed below, we show the graben-like character of the Mill Creek syncline fault block in cross-section $B-B^{\prime}$ to be the result of principally thrust/reverse offsets along its bounding faults, rather than normal offsets that classically characterize grabens.

The Reagan fault is the southern bounding fault of the Mill Creek syncline and separates it from the Tishomingo anticline (cross section $B-B^{\prime}$, fig. 6) and Dougherty anticline (cross section $A-A^{\prime}$, fig. 6) to the south. Ham and others (1954) and 
Johnson (1990) show the Reagan fault as a relatively linear northwest-southeast striking fault that appears to dip steeply. Locally, it has subsidiary fault strands and is expressed as a fault zone. Apparent stratigraphic offsets along the Reagan fault are inconsistent along its strike. Throughout most of its trace in the CNRA map area, the Reagan fault exhibits down-to-the north displacement and it has been mapped and portrayed in existing cross sections as a steeply south dipping, thrust/reverse fault (Ham and others, 1954; Johnson, 1990; Naruk, 1994). Gravity data discussed below also suggest it dips to the south (Scheirer and Scheirer, 2006). Along parts of its trace in the map area, however, it shows down-to-the-south or perhaps right-lateral offset of folded strata, and Johnson (1990) shows the Reagan fault as being both a steeply south-dipping, north-directed thrust fault and, in part, a right-lateral strike slip fault. On the CNRA map and in the cross sections ( $A-A^{\prime}$ and $B-B^{\prime}$ on the map sheet), we similarly show the Reagan fault as a south-dipping, obliqueslip fault that has components of both north-directed reverse/ thrust slip and right-lateral slip. Offset relations along the Reagan fault described above could be the result of two differing episodes of displacement — an episode of strike-slip (rightlateral) displacement followed by, or preceded by, an episode of reverse/thrust displacement. However, these offset relations can also be explained by one episode of oblique-slip (right-lateral/ reverse displacement) as we characterize the Reagan fault on the CNRA geologic map.

The Tishomingo and Dougherty anticlines are well expressed in the southern part of the map area, where they are separated from the Mill Creek syncline block by the Reagan fault (fig. 6). The Tishomingo anticline is a relatively tight fold in much of the southeastern part of the map area, but as it broadens to the southeast, it is cored by the entire sequence of Arbuckle Group and underlying Timbered Hills Group units and Middle Proterozoic granitic rocks (Ham and others, 1954; Johnson, 1990). South and southwest of the map area, the Tishomingo anticline and the continuation of folds southwest of the Dougherty anticline are cut by the Washita Valley fault. This fault is a major southwest-dipping thrust fault that may show left-lateral offset (Brown, 1984; Tanner, 1967; Wickham, 1978). The Tishomingo anticline, and perhaps the entire region between the Reagan and Washita Valley faults, were uplifted during the older Wichita orogeny (see Regional Structural Framework section of this report). North of the Reagan fault, the Deese Group provides evidence for the Wichita orogeny. Timing of Vanoss Formation deposition also constrains the younger Arbuckle orogeny (fig. 6). These Middle and Upper Pennsylvanian units are absent south of the Reagan fault in the CNRA map area, and absent from the larger region that lies between the Reagan fault and Washita Valley fault farther south. Presumably the Deese Group was not deposited in this region that was elevated during the Wichita orogeny, and likely remained elevated during the Desmoinsian-age deposition of the Deese Group that overlapped and followed this orogeny (Cardott and Chaplin, 1993). The Vanoss Formation may not have been deposited or may have been eroded from this region as it remains the topographically highest region of the map area.
Although the Arbuckle's major faults have been mapped at the surface, many more have been identified in the subsurface through geophysical methods, including those identified through seismic, electrical resistivity imaging (ERI), ground-penetrating radar (GPR), and HEM surveys (Halihan and others, 2009; Kennedy, 2008; Riley, 2004; Sample, 2008; Scheirer and Scheirer, 2006; and Smith and others, 2009, 2011). A helicopter electromagnetic/magnetic (HEM) survey flown in 2007 (Smith and others, 2009, 2011) substantiated the results of the gravity survey by Scheirer and Scheirer (2006). Their gravity survey also suggests that the South Sulphur fault dips steeply, the Mill Creek fault zone dips vertically, and the Reagan fault dips to the south, which is consistent with it being mapped as a thrust fault (fig. 3). However, we suggest that the Mill Creek fault zone is too wide and complex to be definitively characterized by gravity data alone. Scheirer and Aboud (2008) later collected ground magnetic and gravity data in the western part of the Hunton anticline near CNRA and Sulphur, Oklahoma. Their investigations suggest that numerous smaller faults throughout the region terminate against the major northwest-trending faults and against each other. These smaller faults are characterized by short linear lengths, small offsets of stratigraphic units, and a variety of orientations (Scheirer and Scheirer, 2006).

The major and subsidiary faults, as well as related fractures and brecciation, were mostly or entirely produced during the Pennsylvanian deformation of the Arbuckle Mountains, and these features contribute significantly to the permeability of the deformed Arbuckle-Simpson aquifer units. In the CNRA map area, the Vanoss Formation disconformably overlies the Arbuckle-Simpson aquifer units, and in the subsurface, the Vanoss Formation is known to act as an upper confining unit for the aquifer. The Vanoss Formation also post-dates nearly all of the Pennsylvanian deformation that folded, faulted, and fractured the older aquifer units. The overall lack of faults and fractures in the Vanoss Formation also contributes to its ability to seal and confine the underlying aquifer.

\section{Karst Features in the Chickasaw National Recreation Map Area}

Some intriguing but poorly understood, circular-shaped hills (fig. 7) occur just outside CNRA in the east-central part of the map area (see map sheet), and similar hills occur elsewhere in the Arbuckle Mountains. These circular hills occur as distinct knobs that range in diameter from about 200 to $800 \mathrm{ft}$ (60 to $250 \mathrm{~m}$ ) and in height from about 50 to $250 \mathrm{ft}$ (15 to $75 \mathrm{~m})$. Although we interpret these features as collapse features related to ancient karst development, they have also been mapped and interpreted as thrust fault-related klippen (Ham, 1945; Lehman, 1945).

Ham and others (1954) mapped and described these knobs as "collapsed areas showing chaotic structure." Similarly, but more generically, Johnson's (1990) modification of Ham and others (1954) map describes these knobs as "areas of brecciated rock showing chaotic structure." These knobs are 
all composed of either the undifferentiated map unit Sylvan Shale/Viola Group (Osv) or the undifferentiated unit Bromide/ Tulip Creek/McLish Formations (Obm). The knobs depositionally or unconformably rest on Simpson Group rocks, either the units Obm (upper part of Simpson Group) or Ooj (lower part of Simpson Group). Measurement of bedding attitudes across the axes of the hills investigated all show a relatively consistent pattern of inward dips towards the center of each hill (Lidke and Blome, 2010)

These circular geomorphic features resemble hills that have been referred to by several names, including "haystack hills" (Parker, 1984). Haystack hills are geomorphic features that occur in karstic carbonate terrains around the world and are commonly interpreted to be the result of differential weathering of relatively flat-lying limestones that are jointed in large rectangles. Although the circular hills near CNRA and in other parts of the Arbuckle Mountains morphologically resemble haystack hills, the deformed strata that underlie these hills suggest that they are not simply the result of differential weathering.

The only other investigations of these knobs were studies by Lehman (1945) and an investigation of these knobs by
Ham (1945) during his mapping of the Arbuckle Mountains. Lehman (1945) mapped and evaluated several of these "knobs" in and around CNRA, presented several possibilities for their origin, and concluded that they were probably klippen, isolated erosional remnants of a large thrust sheet. Ham (1945) also noted some of the collapse characteristics of these features, but like Lehman (1945), concluded that they were klippen and noted that Lehman's study confirmed this conclusion. Ham, however, later showed and described these features as "collapsed areas showing chaotic structure" on the first comprehensive geologic map of the Arbuckle Mountains (Ham and others, 1954). Our investigations revealed that the strata within these circular-shaped hills generally had beds that dipped inwardly toward the hill's axis. These strata also tended to be more deformed (broken) than strata in the surrounding outcrops (Lidke and Blome, 2010).

Consequently, we favor the later interpretation by Ham and others (1954) that these knobs are collapsed areas and probably represent erosionally exhumed karst features. The circular shape of these features and the dips of strata toward the hill's axes collectively suggest that they initially formed

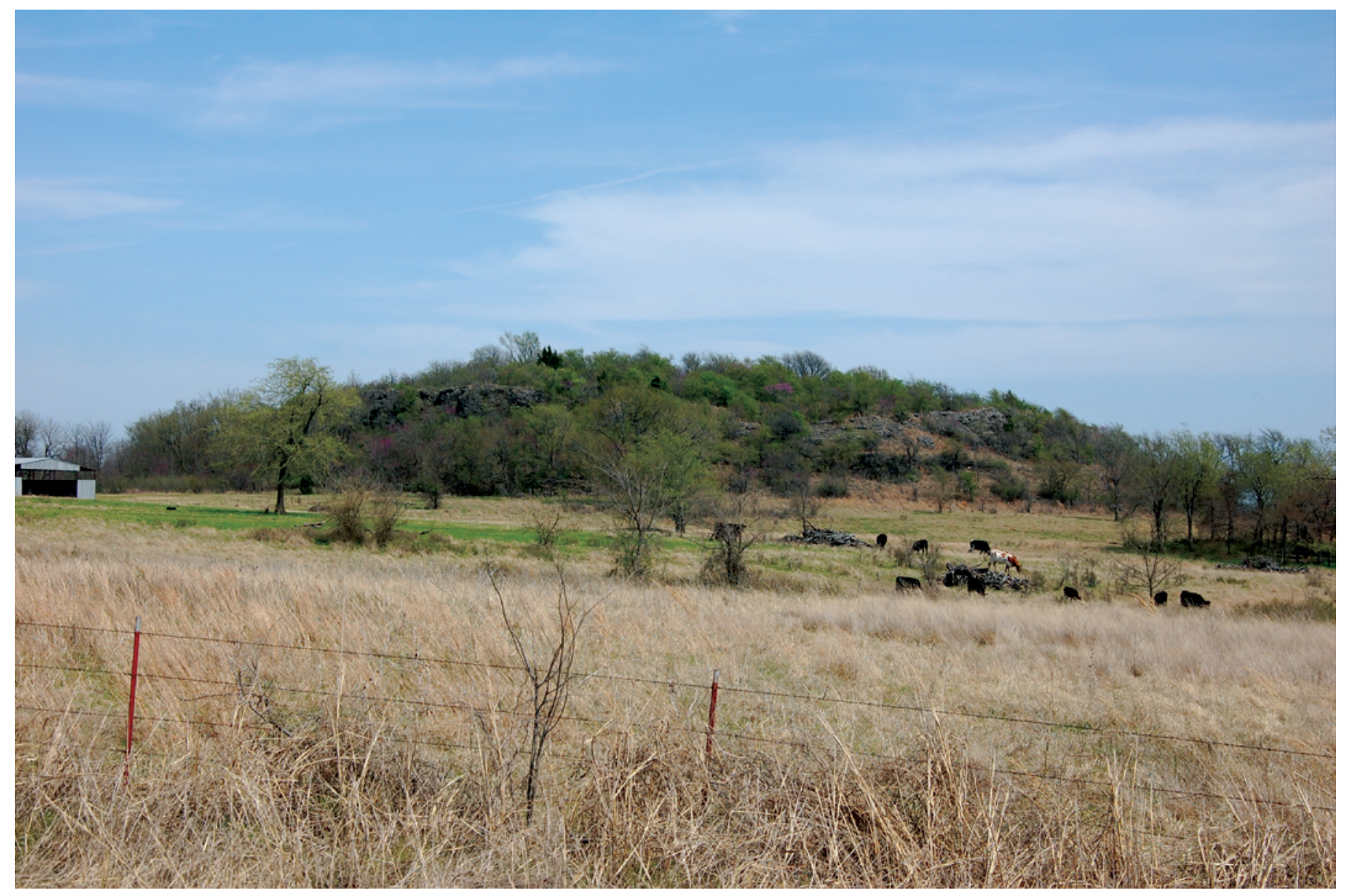

Figure 7. Example of circular-shaped hills present in the eastern parts of the map area and areas to the east. The circular perimeters of the hills and inward dips of the bedding suggest these hills represent erosional remnants of paleo-karst sinkholes. 
as large, sag-like sink holes (Lidke and Blome, 2010). If this interpretation is correct, these large sink holes that now form "knobs" (topographic highs) would require that the collapsed rock units be more resistant to erosion than were the surrounding rocks they collapsed into. Although further study is needed, post-collapse fluids in the sink holes may have altered the collapsed strata, making them more resistant to erosion.

\section{Geologic Mapping}

The geologic map of the area in and around CNRA is a culmination of reconnaissance and detailed geologic investigations that were also part of a much larger study of the geologic framework of the Arbuckle-Simpson aquifer. The geologic map includes both new mapping, and in places, minor modifications or adjustments to previous, smaller-scale geologic maps (for example, Ham and others, 1954; Johnson, 1990).

The CNRA, and much of the surrounding region, is one of dominantly subdued topography and relatively thick vegetation that includes both dense trees and grasses (see fig. 6). Rock exposures are spotty to absent throughout much of the map area because of the vegetation, and in many areas, only float or rubble eroded from near-surface bedrock are present. The southern part of the map area includes the core of the Arbuckle Mountains and has more topographic relief than the remainder of the map area. The best exposures of the rock units occur in this part of the map area where tight folds are prominent in the imagery (see fig. 6). However, even in this part of the map area, thick vegetation commonly obscures rocks units and geologic relations.

Nearly all of the northern part of the CNRA map area, and much of the central part, are underlain by the Late Pennsylvanian Vanoss Formation, which contains both the upper shale facies (Pvs) and lower limestone conglomerate facies $(\mathbb{P v c})$ units. The Vanoss Formation units form the surface exposures and unconformably overlie older, and more deformed, rock units in these parts of the map area. The readily weathered shale facies (PVS) is usually exposed as float or rubble. Although small outcrops of the limestone conglomerate facies ( $\mathbb{P v c}$ ) are more common (fig. $5 E$ ), the thick to massive bedding character of the conglomerate commonly masks the bedding in these spotty, small exposures. As a result, the geologic map shows sparse bedding orientation information (strike and dip symbols) in regions directly underlain by the Vanoss Formation. Where bedding in the Vanoss Formation is apparent, it is predominantly gently dipping to horizontal.

Outside of the Recreation Area, all of the land is privately owned and nearly all of the numerous and variably-sized land parcels are fenced. We did not access every parcel of private land.

\section{Mapping Methodology}

Reconnaissance field mapping in 2008 and 2009 revealed a number of inconsistencies on the Johnson (1990) map, including fault attributes, fault displacement, and thrust direction.
Comparisons among existing geologic maps and the digital map of Cedarstrand (1996) also revealed a number of discrepancies, both in spatial referencing and in content. In 2008, our project began geospatial registration and digitization of existing geologic maps, specifically the 1:72,000- and 1:100,000-scale maps of Ham and others (1954) and Johnson (1990), respectively, and the construction of a GIS database. Map and imagery data of the GIS database used during the mapping and compilation included the following digital data layers: (1) previous geologic maps, (2) topography and shaded relief, (3) National Agriculture Imagery Program (NAIP, http://www.fsa.usda.gov/FSA/apfo app? area $=$ home\&subject $=$ prog\&topic $=$ nai) 2008 one-meter photo mosaics data, and (4) merged 15-meter resolution Landsat 7 ETMplus and Advanced Spaceborne Thermal Emission and Reflection Radiometer (ASTER) data sets.

Database development was followed by fieldwork over a two-year period wherein both previously mapped geologic contacts and fault structures were verified and new mapping was conducted. Field mapping in 2009 and 2010 included the adjustment of unit contacts, faults, and geomorphic features, as well as the addition of new fault structures. Relocation of previously reported unit contacts and new unit contacts was accomplished using field observations as well as computer photographic analyses using the NAIP 2008 1-meter photo mosaic data layer, and merged 15-meter resolution Landsat 7 ETMplus and ASTER data sets. Fault structures were locally verified on the basis of abrupt lithologic or stratigraphic dissimilarities, fault breccia, and linear, sparry calcite deposits. Our fieldwork also showed that a number of formerly undifferentiated rocks units are mappable as individual formations in some areas. Both the upper and lower Hunton Group exposures, and the Sylvan Shale and Viola Group are mappable as separate rock units in parts of the new map.

A small General Dynamics Itronics DuoTouch 2 ${ }^{\mathrm{TM}}$ tablet computer containing these digital data sets was used extensively in the field. This tablet computer, with its built in Geographic Positioning System (GPS), allowed us to compare our field positions to the digital map and imagery data while in the field at specific sites. This capability also allowed us to evaluate and use features and characteristics apparent in the imagery as guides to our mapping. In addition, the site-specific evaluation of imagery characteristics also helped to relocate or adjust contact or fault locations in parts of the map area that we did not, or could not, visit.

\section{Summary}

The Arbuckle-Simpson aquifer in the Arbuckle Mountains of south-central Oklahoma is a critical groundwater resource and accurate, digital geologic mapping at large-scale is an important first step in characterizing the geologic framework of this aquifer system. Chickasaw National Recreation Area is an important part of this aquifer as it contains numerous freshwater and mineral springs that discharge in the Recreation Area's Rock Creek and its principal tributary, Travertine Creek. 
The National Park Service held a Geologic Resources Evaluation scoping meeting at CNRA on October 17-18, 2007, to discuss the potential for mapping the Recreation Area at 1:24,000-scale and to conduct ground geophysical surveys in the northern part of the Recreation Area's Travertine area. The NPS awarded the contract to the USGS in April, 2008. Maps of this scale (or larger) are useful to resource management because they capture most geologic features of interest and are spatially accurate within $40 \mathrm{ft}(12 \mathrm{~m})$.

This USGS report contains a geologic map sheet, which includes cross sections that depict subsurface relations in the map area, and a pamphlet that contains stratigraphic and structural data for areas up to a few miles outside the Recreation Area. The large-scale geologic map of CNRA is at 1:24,000-scale and is underlain by topographic and shaded relief data layers.

This 1:24,000-scale geologic map of CNRA identifies and revises numerous unit contacts and faults and shows that some of the formerly undifferentiated rocks units are locally mappable as individual formations. A helicopter electromagnetic geophysical survey complemented geologic mapping of CNRA by providing additional subsurface contact and fault control in the central and eastern parts of the CNRA.

Small, circular-shaped hills that occur directly east of the CNRA are similar to hills we examined in other areas in the eastern Arbuckle Mountains. We interpret these hills to be erosional remnants and the result of ancient karst-related collapse and subsequent differential erosion that exhumed large sink holes and preserved them as circular-shaped hills. As such, these paleo-karst features also provide insights into the formation of the underlying Arbuckle-Simpson aquifer.

\section{Acknowledgments}

We thank numerous National Park Service personnel at the Sulphur, Oklahoma, office who aided us during our field studies. Numerous landowners near CNRA graciously allowed us access to their land during these studies. R.W. (Bob) Allen of the Oklahoma City Geological Society generously shared with us some of his knowledge and insights regarding structural and stratigraphic relations in the Arbuckle Mountains. Darryl Carter (National Park Service, Consulting Geologist) accompanied us at times during our field studies, advised us on the geology of the region, helped us obtain permission to access some of the private land, and also technically reviewed this map and pamphlet. W.R. (Ric) Page (USGS) provided critical and helpful comments and insights in his technical review. Paco Van Sistine (USGS) was responsible for the GIS and metadata and made suggestions and revisions that improved these data. Theodore R. Brandt prepared the digital topographic base. L.J. Binder (USGS) was responsible for the final editing and layout of the map sheet and pamphlet.

\section{Description of Map Units}

This geologic mapping depicts the surface exposures of the lithostratigraphic units that compose the geology in and around CNRA. Stratigraphic nomenclature and detailed descriptions of the Paleozoic rocks exposed in and around CNRA are from Ham and others (1954), Ham (1973), Fay (1989), Johnson (1990), the USGS National Geologic Map Database GEOLEX (http://ngmdb.usgs.gov/Geolex/geolex.html), and the authors' field observations from 2008 through 2010. The map unit descriptions below include the general lithologies, thickness, fossil groups, and their provincial series according to the guidelines of the U.S. Geological Survey Geologic Names Committee $(2009,2010)$. Geologic provincial series names used are from the geologic time scale of Gradstein and others (2004) and Walker and Geissman (2009). Also included are notes about the unit's type locality or type area (if one exists), and the derivation of the unit's name. Averages and ranges of thickness of each map unit refer to unit thickness in the CNRA, Hunton anticline, and other nearby areas. 


\section{DESCRIPTION OF MAP UNITS}

\section{Quaternary Stratigraphy}

af

Qac

Ps

Pvs

Pvc

$\operatorname{Pd}$

Artificial fill (Quaternary) - Unconsolidated sand, silt, clay, and gravel used as artificial fill at the Lake of the Arbuckles dam site

Alluvium and colluvium, undifferentiated (Quaternary) - Unconsolidated sand, silt, clay, and gravel along rivers and streams that are inundated regularly; includes some terrace deposits and includes small alluvial fan and colluvial deposits along the flanks of major valleys. Thickness varies; ranges from about 3 to $50 \mathrm{ft}$ ( 1 to $15 \mathrm{~m}$ )

\section{Paleozoic Stratigraphy}

Pontotoc Group (Lower Permian and Upper Pennsylvanian)—Divided into three units in descending stratigraphic order: Konawa Formation (not present in the mapped area), Stratford Formation, and Vanoss Formation. The Pontotoc Group ranges from 1,200 to $1,500 \mathrm{ft}$ (366 to $457 \mathrm{~m}$ ) in thickness. Named after Pontotoc County, Oklahoma. No type section designated (Morgan, 1924)

Stratford Formation (Lower Permian)—Red shale and sandstone containing the Hart Limestone Member at its base in the Sulphur area. Grades into limestone conglomerate and arkose towards mountains west of Sulphur. Only exposed in the northwest corner of map area. Middle formation of the Pontotoc Group. Unit about $400 \mathrm{ft}(122 \mathrm{~m})$ thick in Stonewall County, Okla. Named after town of Stratford, western part of Stonewall quadrangle, Garvin County, Okla. (Morgan, 1924)

Vanoss Formation (Upper Pennsylvanian, Virgilian) — Sandstone, conglomerate, shale, and a few thin limestone beds. Underlies Hart Limestone Member of the Stratford Formation in the Sulphur area. Lower unit of Pontotoc Group. Divided into upper shale facies (Pvs) and lower limestone conglomerate facies (Pvc). In the western part of the Arbuckle Mountains, the upper shale facies is partly equivalent to the Stratford Formation. In the Sulphur area, the lower limestone conglomerate facies may include strata equivalent to the Ada Formation. Up to $650 \mathrm{ft}(198 \mathrm{~m})$ thick. Named after the town of Vanoss, Pontotoc County, Okla. (Morgan, 1924)

Upper shale facies - Principally shale and silty shale with some arkosic sandstone interbeds that are more common in lower part. Locally contains thin beds of gray limestone conglomerate. Shale is light in color, ranging through shades of green and gray and locally red and maroon. Arkosic sandstone interbeds are tan to reddish brown, poorly sorted, and fine- to coarse-grained. Sandstone can be so arkosic that it appears granitic. Grades into limestone conglomerate and arkose towards the mountains west of Sulphur. Contact with underlying lower conglomerate facies (Pvc) is gradational. Thickness of unit ranges from 30 to $80 \mathrm{ft}$ ( 9 to $24 \mathrm{~m}$ ) thick

Lower limestone conglomerate facies - Gray, thick to massive bedded limestone conglomerate consisting of limestone boulders, cobbles, and pebbles in a calcareous matrix with finely dispersed clay. Disconformably overlies the Deese Group (Pd) and most of the other older rock units in the map area. Thickness 100 to $500 \mathrm{ft}$ (30 to $152 \mathrm{~m})$; average is $100 \mathrm{ft}(30 \mathrm{~m})$ thick

Deese Group, undifferentiated (Middle Pennsylvanian, Middle Desmoinesian) — Typical lithologies include thick bedded to massive sandstone, gray and red shale, limestone conglomerate, and fossiliferous, light-colored, gray to white limestone. Exposed in the southeastern part of the map area within the Mill Creek syncline, along and near the banks of the Lake of the Arbuckles, and the northern flank of the Arbuckle anticline west of the map area. Deese Group includes, in descending stratigraphic order, the Devils Kitchen Conglomerate, Milsap Lake Formation, and West Arm Formation (undifferentiated in map area). Fossils include crinoids, endothyrids, brachiopods, and mollusks. Disconformably overlies the Springer Formation (PMs) in southeast part of map area and Caney Shale along the northern flank of the Arbuckle anticline west of the map area. Is inferred (based on regional data) to disconformably overlie other older rock units in the subsurface of the map area (see cross section $\boldsymbol{B}-\boldsymbol{B}^{\prime}$, map sheet). Maximum 
thickness of over 9,000 ft (2,743 m). Named for the town of Deese, Carter County, Okla. (Goldston, 1922)

Paw

PMs

Mc

MDsw
Atoka and Wapanucka Formations, undifferentiated (Middle to Lower

Pennsylvanian) - Upper part of this undifferentiated unit (Atoka Formation) is typified by unfossiliferous sandstone and gray to brown shale. The lower part (Wapanucka Formation) includes massive, gray to tan to white limestone and interbedded shale and siltstone. Thickness ranges from 950 to $1,420 \mathrm{ft}(290-433 \mathrm{~m})$. Unit as a whole thins westwardly. Only occurs as fault-bounded wedge in southeast part of map area. Both formations occur separately (outside of mapped area) in the eastern part of the Hunton anticline and are described below.

Atoka Formation (Middle Pennsylvanian, Atokan) — Unfossiliferous, sandstone and dark-gray to -brown siderite-bearing shale. Mapped separately in the eastern part of the Hunton anticline where the total thickness of the Atoka Formation ranges from 950 to $1,260 \mathrm{ft}$ (290-384 m). Most likely named for town of Atoka, Atoka County, Okla. (Taff, 1901)

Wapanucka Formation (Middle to Lower Pennsylvanian, Atokan to Morrowan)Fossiliferous, massive, gray to tan to white limestone that is partly oolitic at top of unit interbedded with shale and siliceous siltstone. Base of unit contains calcareous and cherty sandstone. Fossils include sponges, corals, brachiopods, foraminifers, and ostracodes. Mapped separately only in the northern and eastern parts of the Hunton anticline area where the maximum thickness is about $160 \mathrm{ft}(49 \mathrm{~m})$. Origin of name unknown but probably named for town of Wapanucka, Johnston County, Okla. (Taff, 1901)

Springer Formation (Lower Pennsylvanian to Upper Mississippian, Morrowan to Chesterian) - Dark (black to blue) fissile, bituminous shale separated by thin beds of sandstone and limestone. Contains siderite, ferruginous, and calcareous concretions. Sandstone beds vary from a few feet to tens of feet thick. Maximum thickness to $6,000 \mathrm{ft}(1,829 \mathrm{~m})$, but underlies Middle Pennsylvanian unconformity and preserved thickness can be much less. Includes Goddard Shale Member at its base and includes Union Valley Sandstone Member and equivalents north and east of the map area. Overlies the Caney Shale (Mc) in southeast part of map area. Springer Formation is best exposed in the Criner Hills area, a mountain range which climbs to an altitude of $978 \mathrm{ft}(298 \mathrm{~m})$ in Carter County, Okla.; the Criner Hills are located southwest of CNRA and just southwest of the town of Ardmore, Okla. Fossils include various species of brachiopods, bryozoans, and bivalves. Type area located at the village of Springer, Carter County, Okla. (Tomlinson, 1929).

Caney Shale (Upper to Middle Mississippian, Chesterian to Meramecian) - Darkgray to black, laminated, fissile and friable shale containing septarian and phosphatic concretions. Because the shale is friable, individual outcrops are rarely observed; usually expressed as lush, grassy fields and slopes. Concretions vary in size, up to $3 \mathrm{ft}$ or more in diameter. Unit varies from $90 \mathrm{ft}(27 \mathrm{~m})$ thick in the north to over $200 \mathrm{ft}(61 \mathrm{~m})$ thick in the south part of the Hunton anticline area and to over $400 \mathrm{ft}(122 \mathrm{~m})$ thick in the southwest part of the map and adjacent Arbuckle anticline areas. Invertebrate fossils include conodonts, pelecypods, gastropods, ostracodes, goniatites, and cephalopods. Overlies the Sycamore Limestone (upper part of MDsw) in southeast part of map area. Type section located in Johnston County, Okla. (Elias and Branson, 1959). Named for Johns Valley, formerly called Caney Basin or Cove, Pushmataho County, Okla.

Sycamore Limestone, Welden Limestone, and Woodford Shale, undifferentiated (Mississippian to Devonian) - Exposures typical of the Sycamore Limestone contain shale and argillaceous cherty to silty limestone overlain by shale and marly limestone. Welden Limestone generally not exposed in the Arbuckle Mountains or thinly exposed $(<7 \mathrm{ft}$ or $2 \mathrm{~m}$ ). Typical Woodford Shale exposures are characterized by dark, fissile shale, siliceous shale, bedded chert, and black bituminous shale. Locally, chert and siliceous shale compose most of the Woodford Shale. Unit ranges from 330 to over $1,000 \mathrm{ft}$ (101 to over $305 \mathrm{~m}$ ) thick in the Hunton anticline area. Mapped together over much of the Arbuckle Mountains as the contact between the Woodford Shale and Sycamore Limestone is rarely observed, and the Welden Limestone is very thin to 
absent and rarely exposed. The individual formations composing this undifferentiated map unit are described separately below

\section{Sycamore Limestone (Middle to Lower Mississippian, Meramecian to}

Kinderhookian) - Lower part of formation composed of gray shale and argillaceous cherty and spicular, silty limestone, and calcareous siltstone that is overlain by gray shale and tan-weathering marlstone; limestone fine-grained to silty, weathers to yellowish colors. Unit varies from 130 to $350 \mathrm{ft}(40-107 \mathrm{~m})$ in thickness in the Hunton anticline area. Named for Sycamore Creek, Johnston County, Okla. (Taff, 1903)

Welden Limestone (Lower Mississippian) - Limestone, generally not exposed in the Arbuckle Mountains, or is very thin and commonly misidentified as part of the much thicker Sycamore Limestone (Elias, 1956). Includes light-green, blocky, glauconitic, yellowish weathering shale at base. In the Lawrence uplift area to the northeast of the map area (fig. 3), the Welden Limestone consists of 0 to $5 \mathrm{ft}$ ( 0 to $2 \mathrm{~m}$ ) of light-gray to buff, crystalline, argillaceous, fossiliferous limestone, which weathers to a yellow or orange color. This thin limestone also contains scattered phosphatic nodules similar to those observed in some areas in the upper part of the Woodford Shale. Unit was named by Cooper (1931) for exposures along Welden Creek, Pontotoc County, Okla.

Woodford Shale (Lower Mississippian, Kinderhookian to Upper Devonian)—Lightto dark-gray, fissile shale, siliceous shale, bedded chert, and black, fissile bituminous shale. Locally, siliceous shale and bedded chert make up most of the formation. Chert and phosphatic concretions occur in the lower part of the unit. Thickness varies from 200 to $700 \mathrm{ft}$ (61-213 m); increases in thickness to the south in the Arbuckle Mountains. Derivation of name unknown but assumed to be for the town of Woodford, Carter County, Okla. (Taff, 1902)

DSOh Hunton Group, undifferentiated (Lower Devonian to Upper Ordovician, Cincinnatian)-White limestone and calcareous marlstone. At the base of the unit are white, oolitic limestone beds, silicified in places. Above the oolititic limestone are blueish- and beige-colored limestone and marlstone, with a maximum thickness of $100 \mathrm{ft}(30 \mathrm{~m})$ or more. Upper $50 \mathrm{ft}(15 \mathrm{~m})$ of unit contains thin-bedded marlstone that is fossiliferous, with some beds composed mainly of shell fragments. Chert nodules also occur in the Hunton Group exposures. Total thickness of the Hunton Group varies greatly and ranges from $125 \mathrm{ft}(38 \mathrm{~m})$ to $550 \mathrm{ft}(168 \mathrm{~m})$. This undifferentiated map unit includes as many as seven, thin (locally absent) formations that consist predominantly of varying amounts of limestone, marl, and interbedded shale. In descending stratigraphic order, these seven formations are: the Frisco, Bois d'Arc, Haragan, Henryhouse, Clarita, Cochrane, and Keel Formations. Frisco Formation is not exposed in the map area. Throughout most of the map area and regions nearby, poor exposures and the thin character of these formations require that they be mapped together as one undifferentiated unit. However, in the southeast part of the map area directly southeast of the Lake of the Arbuckles, exposures are adequate to allow subdivision of the Hunton Group (DSOh) into upper and lower parts (Dhu and SOhl, respectively). These parts of the Hunton Group and the formations they comprise are described below. Named for the village of Hunton, Johnston County, Okla. (Taff, 1902)

Dhu Upper part of Hunton Group, undifferentiated (Lower Devonian) - Alternating blueish to white shales and thin-bedded, argillaceous limestone that weathers to yellowish to tan mudstone overlain by thin-bedded, crystalline and noncrystalline limestone with occasional chert and marly lentils and intercalated yellowish shale. Thickness varies from 0 to $256 \mathrm{ft}$ (to $78 \mathrm{~m}$ ), averages $160 \mathrm{ft}(49 \mathrm{~m})$. Mapped separately from Hunton Group (DSOh) only in the southeast part of map area where the Hunton Group is best exposed. Includes two undifferentiated formations of the Hunton Group, the Bois d'Arc and Haragan Formations, which are described separately below.

Bois d'Arc Formation-Thin-bedded, crystalline and noncrystalline limestones with occasional chert and marly lentils and thin beds of intercalated yellow-weathering shale. Uppermost formation of the Hunton Group in the map area. Characteristic fossils include sponges, anthozoans, crinoids, brachiopods, gastropods, crustaceans, and locally corals. Thickness varies from 0 to $90 \mathrm{ft}$ (to $27 \mathrm{~m}$ ), averages $60 \mathrm{ft}(18 \mathrm{~m}$ ). Type area des- 
ignated along Bois d'Arc Creek in the Arkoma basin, Pontotoc County, Okla. (Reeds, 1911)

Haragan Formation-Alternating blueish to white shale, thin-bedded, argillaceous limestone, and yellow- to tan-weathering mudstone. Common fossils are sponges, anthozoans, crinoids, brachiopods, gastropods, and crustaceans. Thickness varies from 0 to $166 \mathrm{ft}$ (to $51 \mathrm{~m}$ ), averages $100 \mathrm{ft}(31 \mathrm{~m})$. Type section in the White Mound region, along Haragan Creek, located 3-4 miles southeast of Dougherty. Named for Haragan Creek, 4 miles southeast of the village of Dougherty, Murray County, Okla. (Reeds, 1911). to blueish and greenish-gray, massive limestone and thin to thick-bedded, crystalline to argillaceous limestone, with interbedded shale in the upper parts of the unit. Thickness varies greatly, reaching a maximum thickness of $295 \mathrm{ft}(90 \mathrm{~m})$; average thickness is $125 \mathrm{ft}(38 \mathrm{~m})$. Mapped separately from Hunton Group (DSOh) only in the southeast part of map area where the Hunton Group is best exposed. Includes four undifferentiated formations of the Hunton Group: Henryhouse, Clarita, Cochrane, and Keel Formations, that are described separately below.

Henryhouse Formation (Silurian) - Blueish, yellowish, and reddish-brown, thin- to thick-bedded limestone and argillaceous limestone with interbeds of yellowish shale in the lower half of unit. Light-gray argillaceous limestone dominates the upper part. Characteristic fossils include anthozoans, crinoids, brachiopods, gastropods, and crustaceans. Thickness varies from 0-220 ft (to $67 \mathrm{~m}$ ), averages $90 \mathrm{ft}(27 \mathrm{~m})$. Named for Henryhouse Creek, Carter County, Okla. (Reeds, 1911)

Clarita Formation (Silurian) — Fossiliferous, coarse- to fine-grained, argillaceous limestone, with most of the limestone fine-grained and argillaceous. Divided into two formal members, the Prices Fall Member, a shale and marl of Early Silurian age, and the overlying Fitzhugh Member, a biomicritic limestone of Middle Silurian age. Contact with the underlying Cochrane Formation marked by shale and thin-bedded limestone. Unit includes foraminifers, conodonts, crinoids, ostracodes, and brachiopods. Maximum thickness $45 \mathrm{ft}$. Type locality located 3 miles west of the village of Clarita, Coal County, Okla. (Amsden, 1957)

Cochrane Formation (Silurian) - White to blueish- and greenish-gray, massivebedded, crystalline limestone containing spherules of glauconite. Unit is, on average, 12 to $15 \mathrm{ft}(4-5 \mathrm{~m})$ thick. Type locality located in Pontotoc County, Okla. (Amsden, 1957) Keel Formation (Upper Ordovician, Cincinnatian) - Fossiliferous, oolitic limestone, and fine-grained, micritic limestone, sometimes recrystallized. Thickness ranges from $0-15 \mathrm{ft}$ (to $5 \mathrm{~m}$ ), generally $5 \mathrm{ft}(2 \mathrm{~m})$ or less thick. Although generally thought to be Early Silurian in age, conodont biostratigraphy (Barrick and others, 1990) indicates that the unit is of Late Ordovician (Cinncinatian) age This undifferentiated map unit has a shaley upper part (Sylvan Shale) and a thicker, limestone-rich lower part (Viola Group). Limestone cherty with occasional chert nodules. Viola Group contains limestone of the Welling Formation and Viola Springs Formation. Cumulative thickness to 1,000 ft (305 m). Basal limestone of the Viola Group overlies limestone and interbedded shale of the upper Simpson Group in many places in the eastern and southern parts of the map area. Throughout the map area and regions nearby, poor exposures require that the Sylvan Shale and Viola Group be mapped together as one undifferentiated unit. However, in the southern part of the map area, south of the Lake of the Arbuckles, exposures are adequate to allow mapping of the Sylvan Shale separately from the Viola Group.

Os Sylvan Shale - Principally green to gray or tan, fissile, calcareous and dolomitic shale that weathers easily and is rarely exposed. Commonly forms swales or subtle rolling hills between resistant underlying and overlying limestone units; locally is silty or siliceous; contains graptolites and chitinozoans (Decker, 1936). Thickness varies from 
$50 \mathrm{ft}(15 \mathrm{~m})$ to up to $300 \mathrm{ft}(91 \mathrm{~m})$ in the Arbuckle Mountains. Named for the village of Sylvan, Johnston County, Okla. (Taff, 1902)

Ov

Viola Group - Composed of limestones of the Welling and Viola Springs Formations. Welling Formation (previously Fernvale Limestone) is gray, coarse-grained, fossiliferous limestone. The Viola Springs Formation is white to blueish-gray, cherty, fine- to medium-grained, locally very fossiliferous limestone with thin interbeds of green to gray, fissile shale; limestone may contain chert nodules in its lower and middle parts. Thickness to $700 \mathrm{ft}(213 \mathrm{~m})$. Named for the village of Viola, Johnson County, Okla. (Taff, 1902)

Simpson Group (Middle Ordovician) - Sandstone and fossiliferous limestone with interbedded greenish shale and marl. Thick, massive brown sandstone lentils occur throughout and range to $100 \mathrm{ft}(30 \mathrm{~m})$ thick. Interbedded limestone and marl lentils are thinner, yellow or blueish, with green, marly shale layers. Simpson Group includes as many as six formations that consist predominantly of limestone, sandstone, and shale. In descending stratigraphic order, these formations are the Bromide, Tulip Creek, McLish, Oil Creek, Joins, and Corbin Ranch Formations. Corbin Ranch Formation is not present in the Hunton anticline and CNRA map areas. These formations are commonly mapped together as two undifferentiated map units, dividing the Simpson Group into upper and lower parts. Basal Simpson Group strata overlie upper Arbuckle Group strata near the southeast corner and east-central border of the map area. Ranges in thickness from $1,000-2,300 \mathrm{ft}(305-700 \mathrm{~m})$. Probably named for the village of Simpson, located north of Pontotoc, Johnston County, Okla. (Taff, 1902)

Obm

Bromide, Tulip Creek, and McLish Formations, undifferentiated - Alternating sandstone, green shale, and limestone. Limestone is buff; shale, grayish-green; sandstone, brown to white and fine- to medium-grained. Includes the upper three formations of the Simpson Group that are described separately below. Tulip Creek not recognized in the eastern part of the Hunton anticline. Thickness is 750-1,400 ft (229-427 m), thinning eastwardly. Decker and Merritt (1931) recognized all three of these formations in their regional summary of the Simpson Group

Bromide Formation-Mostly interbedded limestone and shale with basal quartzose sandstone. Limestone buff-colored, shale grayish-green, and sandstone brown to white. Limestone is commonly fossiliferous with brachiopods and ostracodes. Limestone and minor dolomite in the upper part of the unit are informally called the "upper Bromide limestone." Cooper (1956, p. 120-121) divided the Bromide Formation into two members, the Mountain Lake Member (lower) and the Poolville Member (upper). Thickness of the formation varies, from $315 \mathrm{ft}(96 \mathrm{~m})$ to over $600 \mathrm{ft}(183 \mathrm{~m})$; thickest in the western part of Arbuckle Mountains where it measures $647 \mathrm{ft}(197 \mathrm{~m})$; the basal sandstone unit can vary greatly in thickness, to $300 \mathrm{ft}(91 \mathrm{~m})$ thick. Named for the town of Bromide, Johnston County, Okla. Type locality on a hill northwest of the Galbraith Hotel, Bromide, Okla. (Decker and Merritt, 1931)

Tulip Creek Formation-Mostly shale and sandstone with minor limestone. Shale predominates in the upper part of the unit with sandstone in the lower part. Unit grades upward into the overlying basal sandstone of the Bromide Formation. Commonly has basal sandstone that overlies limestone of the underlying McLish Formation. Unit thickness ranges from 300-400 ft (91-122 m) along the U.S. I-35 corridor (Fay, 1989)

McLish Formation - Comprises the lower part of the undifferentiated Obm map unit in the upper part of the Simpson Group. Mostly interbedded limestone and shale above a quartzose sandstone at the base of the unit; the basal sandstone thins from east to west in the Arbuckle Mountains. Some of the limestone is dense with small blebs of calcite and it is informally termed "birdseye" limestone. Basal sandstone overlies limestone of the underlying Oil Creek Formation. Maximum thickness is $450 \mathrm{ft}(137 \mathrm{~m})$ in the eastern parts of the Arbuckle Mountains and 400-500 ft (122-152 m) thick along the U.S. I-35 corridor (Fay, 1989)

Ooj Oil Creek and Joins Formations, undifferentiated-Limestone, gray to tan, granular, with greenish-gray shale and brown, fine- to medium-grained sandstone. Includes the lower two formations of the Simpson Group that are described separately below. 
Thickness is 600-1,100 ft (183-335 m), decreasing eastward. Decker and Merritt (1931) also recognized both the Oil Creek and Joins Formations in their regional summary of the Simpson Group

Oil Creek Formation-Basal quartz arenite sandstone overlain by limestone and shale. Upper part of unit may also contain some calcite-cemented sandstone. Although sometimes absent in parts of the Arbuckle Mountains, the basal Oil Creek sandstone is the thickest (up to $400 \mathrm{ft}$ or $122 \mathrm{~m}$ thick) of the Simpson Group sandstones and is locally petroliferous (tar sand was mined in the eastern part of the map area) and, in places, is argillaceous or calcareous. Unit averages $750 \mathrm{ft}(229 \mathrm{~m})$ thick. Basal sandstone overlies limestone of the underlying Joins Formation

Joins Formation - Thin-bedded limestone and shale with a persistent thin conglomerate at base of unit. Basal conglomerate overlies, and is derived from, the underlying West Spring Creek Formation. Absent in the eastern part of the Hunton anticline. Unit can be as much as $300 \mathrm{ft}(91 \mathrm{~m})$ thick on the south side of the Arbuckle Mountains

Arbuckle Group (Lower Ordovician to Upper Cambrian) - Includes up to 6,700 ft $(2,042 \mathrm{~m})$ of thin- to massive-bedded limestone and dolomite, with some sandstone and shale, locally subdivided into eight formations (for example, Fay, 1989). The eight formations are, in descending stratigraphic order: the West Spring Creek, Kindblade, Cool Creek, and McKenzie Hill Formations, Butterly Dolomite, Signal Mountain Formation, Royer Dolomite, and Fort Sill Limestone. Throughout much of the Arbuckle Mountains, these formations are commonly lumped together and mapped as three undifferentiated map units that define upper, middle, and lower parts of the Arbuckle Group. Upper and middle parts of the Arbuckle Group are Early Ordovician in age, lower part is Early Ordovician and Late Cambrian in age. Only the West Spring Creek and Kindblade Formations, which compose the upper part of the Arbuckle Group, are exposed in the map area. The Arbuckle Group underlies the Simpson Group in the map area and overlies the Timbered Hills Group elsewhere in the Arbuckle Mountains. "Arbuckle limestone" was first described by Taff (1902) ish to tan dolomite with minor sandstone and shale lentils. Principally limestone in the western part of the Arbuckle Mountains and principally dolomite in the eastern part. In the map area (central Arbuckle Mountains), dolomitic limestone predominates. Interbeds of sandstone are common and more abundant and thicker in the eastern Arbuckle Mountains. These two upper Arbuckle Group formations are mapped together as one undifferentiated unit in the map area, including exposures in the southeast corner and along the central part of the eastern map border. The West Spring Creek Formation is mapped separately where it occurs along the northern part of the eastern border. The Kindblade Formation is only mapped separately east of the map area in the Hunton anticline. The West Spring Creek and Kindblade Formations are described separately below. West Spring Creek Formation - Gray to tan, fine-grained, thick- to thin-bedded, laminated dolomitic limestone and some tan to gray sandstone and shale. Only mapped separately from the Kindblade Formation along northern part of the eastern map border and throughout the core of the Hunton anticline east of the map area. Unit is $1,515 \mathrm{ft} \mathrm{(462} \mathrm{m)} \mathrm{thick} \mathrm{along} \mathrm{the} \mathrm{U.S.} \mathrm{I-35} \mathrm{corridor} \mathrm{(Fay,} \mathrm{1989).} \mathrm{Named} \mathrm{for} \mathrm{a} \mathrm{creek} \mathrm{in}$ southwestern part of Murray County, 4-5 miles southeast of Poolville, Okla. Kindblade Formation-Predominately gray to tan, fine-grained, thick-bedded dolomitic limestone and some sandstone and shale. Only mapped separately where differentiated from the West Spring Creek Formation in the Hunton anticline, east of the map area. Unit is $1,410 \mathrm{ft}(430 \mathrm{~m})$ thick along the U.S. I-35 corridor (Fay, 1989) and generally thins to the east. Derivation of name unknown but assumed to be from the Kindblade Ranch, northeastern Wichita Mountains, Okla. 


\section{References Cited}

Allen, R.W., 2000, Stratigraphy, mountain building and complex geological structures of the Ardmore basin: Oklahoma City Geological Society, Shale Shaker, v. 51, nos. $1-3$, p. $10-21$.

Amsden, T.W., 1957, Introduction to stratigraphy, Part I, in Stratigraphy and paleontology of the Hunton Group in the Arbuckle Mountain region: Oklahoma Geological Survey Circular, no. 44, 57 p.

Bain, H.F., and Taff, J.A., 1904, Preliminary report on the geology of the Arbuckle and Wichita Mountains in Indian Territory and Oklahoma: U.S. Geological Survey Professional Paper 31, $97 \mathrm{p}$.

Barrick, J.E., Klapper, G., and Amsden, T.W., 1990, Stop 1 Hunton Group (Late Ordovician-Early Devonian), in Ritter, S.M., ed., Early to Middle Paleozoic conodont biostratigraphy of the Arbuckle Mountains, southern Oklahoma: Oklahoma Geological Survey Guidebook 27, p. 5-9.

Barthel, C.J., 1985, Hydrogeologic investigation of artesian spring flow-Sulphur, Oklahoma area: Norman, Okla., University of Oklahoma, Master's thesis, 234 p.

Blome, C.D., Faith, J.R., Wahl, R.R., Lidke, D.J., Moore, D.W., and Smith, D.V., 2009, Geologic mapping of the Chickasaw National Recreation Area, south-central Oklahoma [abs.]: Geological Society of America, Abstracts with Programs. v. 41, no. 7, p. 150.

Brown, W.G., 1984, Washita Valley fault system-A new look at an old fault, in Borger, J.G. II, ed., Technical Proceedings of the 1981 American Association of Petroleum Geologists mid-continent regional meeting: Oklahoma City Geological Society, p. 68-80.

Cardott, B.J., and Chaplin, J.R., 1993, Guidebook for selected stops in the western Arbuckle Mountains, Southern Oklahoma: Oklahoma Geological Survey Special Publication 93-3, 55 p.

Cates, S.W., 1989, Fault distribution in the Sulphur, Oklahoma, area based on gravity, magnetic and structural data: Norman, Okla., University of Oklahoma, Master's thesis, 106 p.

Cederstrand, J.R., 1996, Digital geologic map of ArdmoreSherman quadrangles, south-central Oklahoma: U.S. Geological Survey Open-File Report 96-370, scale 1:250,000, http://ok.water.usgs.gov/gis/geology.

Christenson, Scott, Osborn, N.I., Neel, C.R., Faith, J.R., Blome, C.D., Puckette, James, and Pantea, M.P., 2011, Hydrogeology and simulation of groundwater flow in the Arbuckle-Simpson Aquifer, south-central Oklahoma: U.S. Geological Survey Scientific Investigations Report 2011-5029, 104 p.
Cooper, C.L., 1931, Map of the Arbuckle Mountains: Oklahoma Geological Survey Bulletin 55.

Cooper, G.A., 1956, Chazyan and related brachiopods: Smithsonian Miscellaneous Collections, v. 127, part 1, 1,245 p.

Decker, C.E., and Merritt, C.A., 1931, The stratigraphy and physical characteristics of the Simpson group: Oklahoma Geological Survey Bulletin, no. 55, 112 p.

Decker, C.E., 1936, Some tentative correlations on the basis of graptolites of Oklahoma and Arkansas: American Association of Petroleum Geologists Bulletin, v. 20, no. 3, p. 301-311.

Donovan, R.N., 1995, The Slick Hills of Oklahoma and their regional tectonic setting: Oklahoma Geological Survey Circular 97, p. 178-186.

Elias, M.K., 1956, Upper Mississippian and Lower Pennsylvanian formations of south-central Oklahoma, in Hicks, I.C., and others, eds., Petroleum geology of southern Oklahoma-A symposium; v. 1: American Association of Petroleum Geologists Special Volume 16, p. $56-134$.

Elias, M.K., and Branson, C.C., 1959, Type section of the Caney Shale: Oklahoma Geological Survey Circular, no. 52, $24 \mathrm{p}$.

Fairchild, R.W., Hanson, R.L., Davis, R.E., 1990, Hydrology of the Arbuckle Mountains area, south-central Oklahoma: Oklahoma Geological Survey, Circular 91, 112 p., 2 map sheets, 1:100,000 scale.

Faith, J.R., Blome, C.D., Pantea, M.P., Puckette, J.D., Halihan, Todd, Osborn, Noel, Christenson, Scott, Pack, Skip, 2010, Three-dimensional geologic model of the ArbuckleSimpson aquifer, south-central Oklahoma: U.S. Geological Survey Open-File Report 2010-1123, 29 p.

Fay, R.O., 1989, Geology of the Arbuckle Mountains along Interstate 35, Carter and Murray Counties, Oklahoma: Oklahoma Geological Survey Guidebook 26, 50 p.

Gradstein, Felix, Ogg, James, and Smith, Alan, eds., 2004, A geologic time scale 2004: Cambridge, U.K., Cambridge University Press, $589 \mathrm{p}$.

Graham, John, 2008, Geologic Resource Evaluation Scoping Summary, Chickasaw National Recreation Area, Oklahoma: National Park Service, Geologic Resources Inventory Publication 2008-0131, 15 p. http://www.nature.nps.gov/geology/ inventory/publications/s_summaries/CHIC_scoping_ summary_2008-0131.pdf.

Goldston, W.L., Jr., 1922, Differentiation and structure of the Glenn Formation: American Association of Petroleum Geologists Bulletin, v. 6, no. 1, p. 1-23. 
Halihan, Todd, Puckette, Jim, Sample, Michael, and Riley, Mathew, 2009, Electrical resistivity imaging of the Arbuckle-Simpson Aquifer-Report for the ArbuckleSimpson hydrology study: Stillwater, Okla., Oklahoma State University, for the Oklahoma Water Resources Board, 93 p., http://www.owrb.ok.gov/studies/groundwater/ arbuckle_simpson/pdf/2009_Reports/ElectricResistivity ImagingArbuckle_Halihan.pdf.

Ham, W.E., 1945, Geology and glass sand resources, central Arbuckle Mountains, Oklahoma: Oklahoma Geological Survey Bulletin, no. 65, 103 p.

Ham, W.E., 1955, Geology of the Arbuckle Mountain region: Oklahoma Geological Survey Guidebook 3, 61 p.

Ham, W.E., 1973, Regional Geology of the Arbuckle Mountains, Oklahoma: Oklahoma Geological Survey Special Publication 73-3, $61 \mathrm{p}$.

Ham, W.E, McKinley, M.E., and others, 1954, Geologic map and sections of the Arbuckle Mountains, Oklahoma: Oklahoma Geological Survey Map A-2, scale 1:72,000.

Hanson, R.L., and Cates, S.W., 1994, Hydrology of the Chickasaw National Recreation Area, Murray County, Oklahoma: U.S. Geological Survey Water-Resources Investigations Report 940-4012, 83 p.

Hart, D.L., Jr., 1974, Reconnaissance of the water resources of the Ardmore and Sherman quadrangles, southern Oklahoma: Oklahoma Geological Survey, Hydrologic Atlas Map HA-3, 1:250,000 scale.

Heran, W.D., Green, G.N., and Stoeser, D.B., compilers, 2003, A Digital Geologic Map Database for the State of Oklahoma: U.S. Geological Survey Open-File Report 03-247, http://pubs.usgs.gov/of/2003/ofr-03-247/.

Johnson, K.S., Burchfield, M.R., and, Harrison, W.E., 1984, Guidebook for the Arbuckle Mountain Field Trip, Southern Oklahoma: Oklahoma Geological Survey Special Publication 84-1, $21 \mathrm{p}$.

Johnson, K.S., 1990, revision of Ham, W.E., McKinley, M.E., and others, 1954, Geologic map and sections of the Arbuckle Mountains, Oklahoma: Oklahoma Geological Survey, Geologic Map GM-31, scale 1:100,000.

Jusczuk, S.J., 2002, How do the structures of the late Paleozoic Quachita thrust belt relate to the structures of the southern Oklahoma aulacogen: Lexington, Ky., University of Kentucky, Ph.D Thesis, 339 p., 23 plates, http://uknowledge.uky.edu/gradschool_diss/index.44. html\#year_2002.

Keller, G.R., and Baldridge, W.S., 1995, The southern Oklahoma aulacogen, in Olsen, K.H., ed., Continental riftsEvolution, structure, tectonics: Developments in Geotectonics, v. 25 , p. $427-436$.
Kennedy, Breanne, 2008, Seismic features of the ArbuckleSimpson aquifer determined from surveys at three different geologic scales: Norman, Okla., University of Oklahoma, Master's thesis, $81 \mathrm{p}$.

Lehman, R.P., 1945, Thrust faulting in the Arbuckle Mountains, Oklahoma: Bulletin of the American Association of Petroleum Geologists, v. 28, no. 2, p. 187-209.

Lidke, D.J., and Blome, C.D., 2010, Possible topographic inversion of karst features in the eastern Arbuckle Mountains, south-central Oklahoma [abs.]: Geological Society of America, Abstracts with Programs, v. 42, no. 5, p. 279.

Marshak, S., Nelson, W.J., and McBride, J., 2003, Phanerozoic strike-slip faulting in the continental interior platform of the United States-Examples from the Laramide Orogen, Midcontinent, and Ancestral Rocky Mountains: Geological Society of London, Special Publications 2003, v. 210, p. 159-184.

Morgan, G.D., 1924, Geology of the Stonewall quadrangle, Oklahoma: Oklahoma Bureau of Geology Bulletin, no. 2, $248 \mathrm{p}$.

Naruk, S.J., 1994, Geometric analyses and balanced cross sections of the Arbuckle Mountains and Washita Valley fault: Oklahoma City Geological Society, Shale Shaker, v. 45, p. 158-162.

Parker, G.G., Sr., 1984, Piping and pseudokarst [abs.]: Geological Society of America, Abstracts with Programs, v. 16, no. 6, p. 618 .

Puckette, Jim, Halihan, Todd, and Faith, Jason, 2009, Characterization of the Arbuckle-Simpson Aquifer-Final Report for the Arbuckle-Simpson hydrology study: Sillwater, Okla., Oklahoma State University, School of Geology, for the Oklahoma Water Resources Board, 53 p., http://www.owrb. ok.gov/studies/groundwater/arbuckle_simpson/pdf/2009_ Reports/Characterization_Puckette/2009_Puckette\%20 et\%20al_Characterization\%20of\%20the\%20Arbuckle\%20 Simpson.pdf.

Reeds, C.A., 1911, The Hunton formation of Oklahoma: American Journal of Science, 4th series, v. 32, no. 190, p. $256-268$.

Riley, M.E., 2004, Investigation of fault properties using electrical resistivity imaging: Norman, Okla., Oklahoma State University, Master's thesis, $104 \mathrm{p}$.

Sample, M.S., 2008, Characterization of the epikarst over the Hunton anticline, Arbuckle-Simpson aquifer, Oklahoma: Norman, Okla., Oklahoma State University, Master's thesis, $220 \mathrm{p}$.

Scheirer, D.S., and Scheirer, A.H., 2006, Gravity investigations of the Chickasaw National Recreation Area, southcentral Oklahoma: U.S. Geological Survey Open-file Report 2006-1083, 42 p. 
Scheirer, D.S., and Aboud, Essam, 2008, Preliminary gravity and ground magnetic data in the Arbuckle Uplift near Sulphur, Oklahoma: U.S. Geological Survey Open-File Report 2008-1003, 34 p.

Smith, B.D., Smith, D.V., Deszcz-Pan, Maryla, Blome, C.D., and Hill, Patricia, 2011, Helicopter electromagnetic and magnetic geophysical survey data, Hunton anticline, south central Oklahoma: U.S. Geological Survey Open-File Report 2011-1240, 15 p.

Smith, D.V., Deszcz-Pan, Maryla, and Smith, B.D., 2009, Depth section imaging for portions of an airborne geophysical survey of the Hunton anticline, southcentral Oklahoma-Final administrative report to the Oklahoma Water Resources Board in fulfillment of the cooperative agreement \#08C7OK002032407: U.S. Geological Survey for the Oklahoma Water Resources Board, http://www.owrb.ok.gov/studies/groundwater/ arbuckle_simpson/pdf/2009_Reports/DepthSectionI magingAirborneGeophysicalSurveyHuntonAnticline _ SmithDeszczPanSmith.pdf.

Stoeser, D.B., Green, G.N., Morath, L.C., Heran, W.D., Wilson, A.B., Moore, D.W., and Van Gosen B.S., 2007, Preliminary integrated geologic map databases for the United States: Central States: U.S. Geological Survey Open-file Report 2005-1351, ver. 1.2, (Revised December 2007), http://pubs.usgs.gov/of/2005/1351/.

Taff, J.A., 1901, Description of the Colgate quadrangle (Indian Territory): U.S. Geological Survey Geologic Atlas of the United States, Colgate Folio, no. 74, 6 p.

Taff, J.A., 1902, Description of the Atoka quadrangle (Indian Territory): U.S. Geological Survey Geologic Atlas of the United States, Atoka Folio, no. 79, 8 p.
Taff, J.A., 1903, Description of the Tishomingo quadrangle (Indian Territory): U.S. Geological Survey Geologic Atlas of the United States, Tishomingo Folio, no. 98, 8 p.

Taff, J.A., 1928, Preliminary report on the geology of the Arbuckle and Wichita Mountains in Indian Territory and Oklahoma: Oklahoma Geological Survey Bulletin 12, 95 p.

Tanner, W.F., 1963, Tectonic patterns in AppalachianQuachita-Oklahoma mountain complex: Oklahoma City Geological Society, Shale Shaker, v. 14, no. 3, p. 2-6

Tomlinson, C.W., 1929, The Pennsylvanian System in the Ardmore basin: Oklahoma Geological Survey Bulletin, no. $46,79 \mathrm{p}$.

U.S. Geological Survey Geologic Names Committee, 2009, Divisions of geologic time-Major chronostratigraphic and geochronologic units: Stratigraphy, v. 6, no. 2, p. 90-92.

U.S. Geological Survey Geologic Names Committee, 2010, Divisions of geologic time-Major chronostratigraphic and geochronologic units: U.S. Geological Survey Fact Sheet 2010-3059, 2 p.

Walker, J.D., and Geissman, J.W., 2009: Commentary-2009 GSA Geologic Time Scale: Geological Society of America, GSA Today, p. 60-61.

Wickham, J.S., 1978, The southern Oklahoma Aulacogen, in Denison, R.E., and Wickham, J.S., eds., Structural style of the Arbuckle region, Geological Society of America Guidebook, South Central Section, Field Trip no. 3, March 8-9, 1978: Geological Society of America Guidebook, p. 9-41.

Williams, D.B., 1983, Structural and geochemical study of the South Sulphur asphalt deposits, Murray County, Oklahoma: Norman, Okla., University of Oklahoma, Master's thesis, $163 \mathrm{p}$.

Publishing support provided by:

Denver Publishing Service Center

For more information concerning this publication, contact:

Center Director, USGS Geosciences and Environmental Change Science Center

Box 25046, Mail Stop 980

Denver, CO 80225

(303) 236-5344

Or visit the Geosciences and Environmental Change Science Center Web site at:

http://gec.cr.usgs.gov/ 


$$
\text { 䞡 }
$$

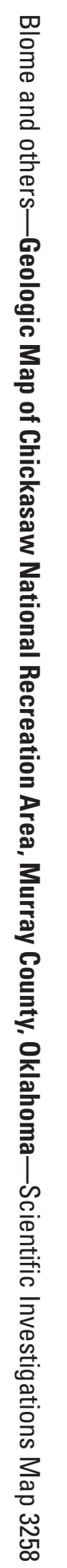

